Final Report

\title{
UNDERSTANDING THE MECHANISMS CONTROLLING ENVIRONMENTALLY- ASSISTED INTERGRANULAR CRACKING OF NICKEL-BASE ALLOYS
}

For the period

December 1, 1999 through November 30, 2003

Gary S. Was, PI, PD

Department of Nuclear Engineering and Radiological Sciences

The University of Michigan

Ann Arbor, MI 48109

February, 2004

Prepared for

THE U.S. DEPARTMENT OF ENERGY

AGREEMENT NO DE-FG02-85ER45184 


\section{SUMMARY}

Creep and IG cracking of nickel-base alloys depend principally on two factors - the deformation behavior and the effect of the environment. We have shown that both contribute to the observed degradation in primary water. The understanding of cracking does not lie wholly within the environmental effects arena, nor can it be explained only by intrinsic mechanical behavior. Rather, both processes contribute to the observed behavior in primary water. In this project, we had three objectives: 1) to verify that grain boundaries control deformation in Ni$16 \mathrm{Cr}-9 \mathrm{Fe}$ at $\left.360^{\circ} \mathrm{C}, 2\right)$ to identify the environmental effect on IGSCC, and 3) to combine CSLBs and GBCs to maximize IGSCC resistance in $\mathrm{Ni}-\mathrm{Cr}-\mathrm{Fe}$ in $360^{\circ} \mathrm{C}$ primary water.

Experiments performed in hydrogen gas at $360^{\circ} \mathrm{C}$ confirm an increase in the primary creep rate in Ni-16Cr-9Fe at $360^{\circ} \mathrm{C}$ due to hydrogen. The creep strain transients caused by hydrogen are proposed to be due to the collapse of dislocation pile-ups, as confirmed by observations in HVEM. The observations only partially support the hydrogen-enhanced plasticity model, but also suggest a potential role of vacancies in the accelerate creep behavior in primary water.

In high temperature oxidation experiments designed to examine the potential for selective internal oxidation in the IGSCC process, cracking is greatest in the more oxidizing environments compared to the low oxygen potential environments where nickel metal is stable. In Ni-Cr-Fe alloys, chromium oxides form preferentially along the grain boundaries, even at low oxygen potential, supporting a potential role in grain boundary embrittlement due to preferential oxidation.

Experiments designed to determine the role of grain boundary deformation on intergranular cracking have established, for the first time, a cause-and-effect relationship between grain boundary deformation and IGSCC. That is, grain boundary deformation in Ni$16 \mathrm{Cr}-9 \mathrm{Fe}$ in $360^{\circ} \mathrm{C}$ primary water leads to IGSCC of the deformed boundaries. As well, the activation energy for grain boundary diffusion driving grain boundary deformation, $Q_{\mathrm{HAB}}=231$ $\mathrm{kJ} / \mathrm{mole}$, is comparable to that for IGSCC initiation (212-241 kJ/mole), suggesting that grain boundary deformation is also the rate limiting factor for crack initiation.

The resistance to IGSCC of Ni-16Cr-9Fe can be maximized by combining grain boundary misorientation with grain boundary carbide precipitation. Taken separately, an increased coincident site lattice fraction, and precipitation of grain boundary carbides increase the resistance to IGSCC initiation in $360^{\circ} \mathrm{C}$ primary water. In combination, the increase in resistance is greater than either of the effects taken separately. The grain boundary carbides tend to prefer the high angle boundaries, and thus, the combined treatment affords greater resistance by protecting a higher fraction of grain boundaries than either taken separately. 


\section{CONTENTS}

Page

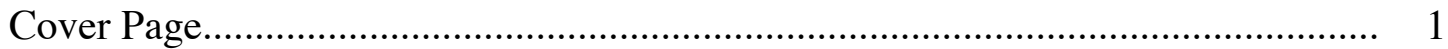

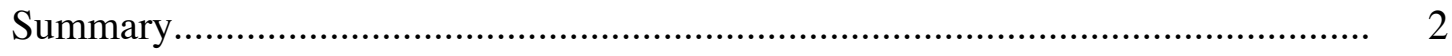

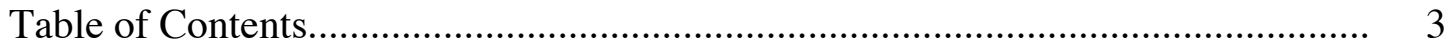

1. ROLE OF GRAIN BOUNDARIES IN DEFORMATION OF

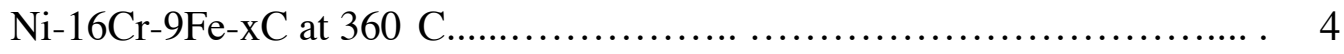

2. EFFECT OF HYDROGEN ON CREEP IN HIGH PURITY Ni-16Cr-9Fe at

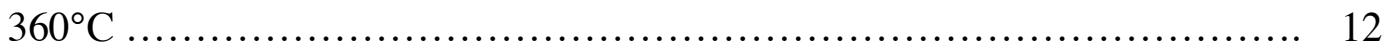

3. SELECTIVE INTERNAL OXIDATION AS A MECHANISM OF IGSCC.... 18

4. MAXIMIZING IGSCC RESISTANCE THROUGH CONTROL OF CSLBs

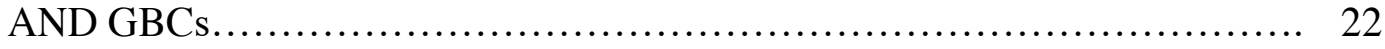

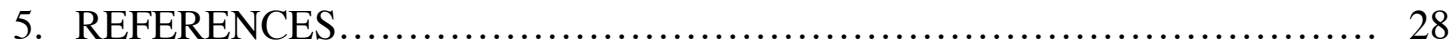

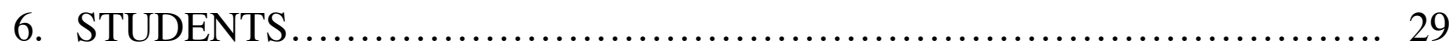

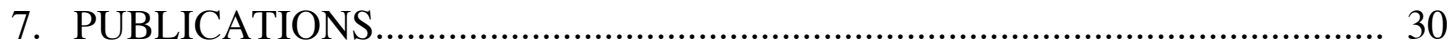




\section{EFFECT OF HYDROGEN ON CREEP IN HIGH PURITY Ni-16Cr-9Fe AT $360^{\circ} \mathrm{C}$}

Experiments designed to evaluate the role of hydrogen on creep have generally been conducted in a primary water environment at $360^{\circ} \mathrm{C}$. However, there are specific problems with primary water tests that make identifying a hydrogen mechanism difficult. First, it is not clear if dissolved hydrogen in the primary water or the hydrogen produced by corrosion is responsible for the increase in creep rate. Since dissolved hydrogen is present even under anodic polarization, where hydrogen reduction is suppressed at the sample surface, hydrogen is still present in PW that may affect deformation. Second, all nickel-base alloys in primary water develop an oxide film that can affect the ingress and transport of hydrogen in the sample. Finally, even in controlled potential tests in which a counter electrode is used to separate the corrosion reactions, it is possible that some anodic dissolution may occur at the sample surface during cathodic polarization and vice versa with hydrogen reduction during anodic polarization. While previous studies of creep in primary water were designed to determine the corrosion reactions that are responsible for the enhancement of creep [1] by examining parameters affected only by hydrogen, such as activation area, it is impossible to know for certain that the observed effects are due to hydrogen alone. Therefore, constant load tensile experiments in a hydrogen gas environment were designed to determine the effect of hydrogen alone on creep. The purpose was to examine the direct effect of hydrogen on steady state creep rate and strain, and determine if hydrogen alone can account for increased creep strains and rates observed in primary water.

\subsection{Effect of dissociated hydrogen gas on creep}

The set of experiments designed to investigate the creep response when hydrogen is introduced once steady state is established showed that hydrogen causes a reproducible strain transient upon introduction to the retort. However, there was no overall effect on the steady state creep rate. The $\%$ creep strain vs. time for tests on several samples are shown in Fig. 1. The size of the strain transients was between $0.11 \%$ and $0.15 \%$. The creep rates during the transients, designated by " $\mathrm{H}^{1 "}$ in Table 1 , were between $2.3 \times 10^{-7}$ and $9.5 \times 10^{-7} \mathrm{~s}^{-1}$. The steady state creep rate in hydrogen was between $1.9 \times 10^{-8} \mathrm{~s}^{-1}$ and $3.9 \times 10^{-8} \mathrm{~s}^{-1}$.

Two H-to-Ar changes were performed to ensure that the change in gas was not responsible for the strain transients. The \% creep strain vs. time during the gas change for both 
tests is shown in Fig. 2. No strain transients were observed when changing from $\mathrm{H}$ to Ar. Also, the creep rate after changing back to Ar was not significantly different than the creep rate in $\mathrm{H}$ (test 159/2 in Table 1).

Table 1: Results of CLTs performed in 0.01 torr argon and dissociated hydrogen $(\mathrm{H})$ for experiments where the environment was switched between argon and hydrogen at $360^{\circ} \mathrm{C}$. Samples were UHP11, $35 \square \mathrm{m}$ grains, and solution annealed. Applied stress $=400 \mathrm{MPa}$.

Filament current $=6$ amps.

\begin{tabular}{|c|c|c|c|c|c|}
\hline $\begin{array}{l}\text { Type of gas } \\
\text { change }\end{array}$ & $\begin{array}{c}\text { Test } \\
\text { number }\end{array}$ & Gas & $\begin{array}{c}\text { Creep rate } \\
\left(\mathrm{s}^{-1}\right)\end{array}$ & $\begin{array}{c}\text { Transient } \\
(\% \square)\end{array}$ & $\begin{array}{l}\text { Time delay } \\
\text { (min.) }\end{array}$ \\
\hline \multirow{4}{*}{ Ar to $\mathrm{H}$} & $159 / 1$ & $\begin{array}{c}\mathrm{Ar} \\
\mathrm{H}^{1} \\
\mathrm{H}\end{array}$ & $\begin{array}{c}3 \times 10^{-8} \\
2.3 \times 10^{-7} \\
2.8 \times 10^{-8}\end{array}$ & 0.15 & $20-25$ \\
\hline & $159 / 2$ & $\begin{array}{c}\mathrm{Ar} \\
\mathrm{H}^{1} \\
\mathrm{H}\end{array}$ & $\begin{array}{l}9.7 \times 10^{-9} \\
8.7 \times 10^{-7} \\
3.9 \times 10^{-8}\end{array}$ & 0.11 & 0 \\
\hline & $159 / 3$ & $\begin{array}{l}\mathrm{Ar} \\
\mathrm{H}^{1} \\
\mathrm{H}\end{array}$ & $\begin{array}{l}8.2 \times 10^{-9} \\
9.5 \times 10^{-7} \\
9.3 \times 10^{-9}\end{array}$ & 0.14 & $20-25$ \\
\hline & $16 / 4$ & $\begin{array}{c}\mathrm{Ar} \\
\mathrm{H}^{1} \\
\mathrm{H}\end{array}$ & $\begin{array}{c}2.7 \times 10^{-8} \\
3 \times 10^{-7} \\
1.9 \times 10^{-8}\end{array}$ & 0.15 & 0 \\
\hline \multirow[t]{2}{*}{$\mathrm{H}$ to $\mathrm{Ar}$} & $159 / 2$ & $\begin{array}{l}\mathrm{H} \\
\mathrm{Ar}\end{array}$ & $\begin{array}{l}3.9 \times 10^{-8} \\
2.5 \times 10^{-8}\end{array}$ & 0.0 & - \\
\hline & $159 / 3$ & $\begin{array}{c}\mathrm{H} \\
\mathrm{Ar}^{2}\end{array}$ & $\begin{array}{c}9.3 \times 10^{-9} \\
\text { no rate }\end{array}$ & 0.0 & - \\
\hline Ar to $\mathrm{Ar}$ & $159 / 3$ & $\begin{array}{l}\mathrm{Ar} \\
\mathrm{Ar}^{2}\end{array}$ & $\begin{array}{c}4.4 \times 10^{-8} \\
\text { no rate }\end{array}$ & 0.0 & - \\
\hline
\end{tabular}

indicates creep rate during transient

2 no rate determined due to failure of filament - test interrupted

\subsection{Creep in primary water and argon}

The $\%$ creep strain vs. time for the CLTs in argon and primary water are shown in Fig. 3. The creep curves are for the initial loading at $455 \mathrm{MPa}$ and then for the decrease in stress to 445 $\mathrm{MPa}$. The average steady state creep rates for the $455 \mathrm{MPa}$ and the $455 \mathrm{MPa}$ regions in both primary water and argon are summarized in the figure. The average steady state creep rate in argon at stresses of 455 and $445 \mathrm{MPa}$ were $2.9 \times 10^{-8} \mathrm{~s}^{-1}$ and $5.0 \times 10^{-9}$, respectively. In primary water, the average steady state creep rates at 455 and $445 \mathrm{MPa}$ were $1.4 \times 10^{-7}$ and $3.3 \times 10^{-8} \mathrm{~s}^{-1}$, respectively. The figure shows that the steady state creep rates in primary water are higher than 
those in argon by a factor of 4.8 and 6.6 for the stresses of $455 \mathrm{MPa}$ and $445 \mathrm{MPa}$, respectively. The internal stress for each environment was determined from the Barrett and Nix model for creep. [2] The creep rate model was modified to include the internal stress. The internal stress was determined by the best fit of the experimental creep rate vs. applied stress data as discussed in ref. 1. The internal stress in primary water was determined to be $370 \mathrm{MPa}$, while in argon the internal stress was $388 \mathrm{MPa}$.

The primary creep regime of in primary water and argon was also examined. The samples tested in primary water demonstrated normal primary creep, while in argon most samples demonstrated inverse primary creep. The primary creep regime for argon and primary water conditions of Fig. 4a are plotted on a finer scale in Fig. 4b. Because of the difference in the primary creep behavior, the primary creep strain was determined from the creep strain at 20 hours. The value of the $\%$ creep strain at 20 hours was higher in primary water $(2.02 \%)$ than in argon $(0.54 \%)$. The primary creep rate in primary water averaged $1 \times 10^{-7} \mathrm{~s}^{-1}$, while in argon the average primary creep rate creep rate was $4 \times 10^{-8} \mathrm{~s}^{-1}$. The average primary creep rate was a factor of 2.5 higher in primary water than in argon.

\subsection{Dislocation behavior in the presence of hydrogen gas - in-situ straining}

The introduction of hydrogen into the environmental cell of the HVEM caused stationary dislocations in a pileup to glide, and reduced the inter-dislocation spacing. Once hydrogen was removed, the dislocations remained in their final positions at the maximum pressure. The original positions of one selected dislocation pile-up are shown in Fig. 5a after straining and immediately before hydrogen was introduced ( 0 torr). Each dislocation is labeled with a letter, and an immobile dislocation was chosen as a reference point. By 80 torr of hydrogen, the dislocations have moved into the closest positions. The dislocation positions at 80 torr are shown in Fig. 5b. Removal of the hydrogen resulted in little dislocation movement either closer together or away from each other.

Figure 6 shows the dislocation distance from the reference point normalized by the initial ( 0 torr) position as a function of the hydrogen gas pressure in the cell. Each curve represents the normalized distance between the dislocation and the reference point at the midpoint of the slip band. The dislocations labeled F-G in Figure 5 were measured from the reference point once they entered the image. Dislocation E moved out of the image early in the experiment and thus 
its distance from the reference point was not measured. Figure 6 indicates that as the hydrogen pressure increases, the inter-dislocation. spacing is reduced. The largest change in spacing occurred by 37 torr of hydrogen in the cell, and the reduction ranged between 8 and $47 \%$. After that, the dislocation spacing decreased at a slower rate. The total decrease in spacing by 80 torr of $\mathrm{H}_{2}$ was between 27 and $51 \%$.

\subsection{Conclusions}

The conclusions of the analysis of results are as follows:

- Exposure of the alloy to hydrogen before loading is required for any increase in the steady state creep rate to be observed. Combined with previous observation in primary water, this result indicates the importance of the environment in primary creep, and subsequently the overall creep behavior of the alloy.

- The faster primary creep rates in primary water may be due to reduced work hardening in the beginning of the creep process. This observation is consistent with the measured reduction in internal stress and the reduction in the work hardening rate of the alloy in primary water also measured by others.

- The transients in the creep strain, when hydrogen is introduced after steady state is established, are proposed to be due to the collapse of dislocation pileups. The size of the strain transients can be accounted for by a reduction in dislocation spacing of $\sim 20 \%$, and this value is consistent with reduction in dislocation spacing observed in the HVEM.

- The results from this study indicate that hydrogen can increase the creep rate of UHP Ni16Cr-9Fe alloys, but do not definitively support a model in which only hydrogen enhanced plasticity is the sole cause of enhanced creep in primary water. The lack of a hydrogen effect on the steady state creep indicates that vacancies may work in concert to accelerate creep in primary water.

- Many SCC models predict that the deformation rate of the metal at the crack tip can control the overall crack growth rate, or rely on a sudden increase in plasticity at the crack tip for the crack propagation. The fact that hydrogen has been shown to cause strain bursts in steady state and that primary water increases the creep rate of the alloy may have significant bearing on cracking of the alloy. 


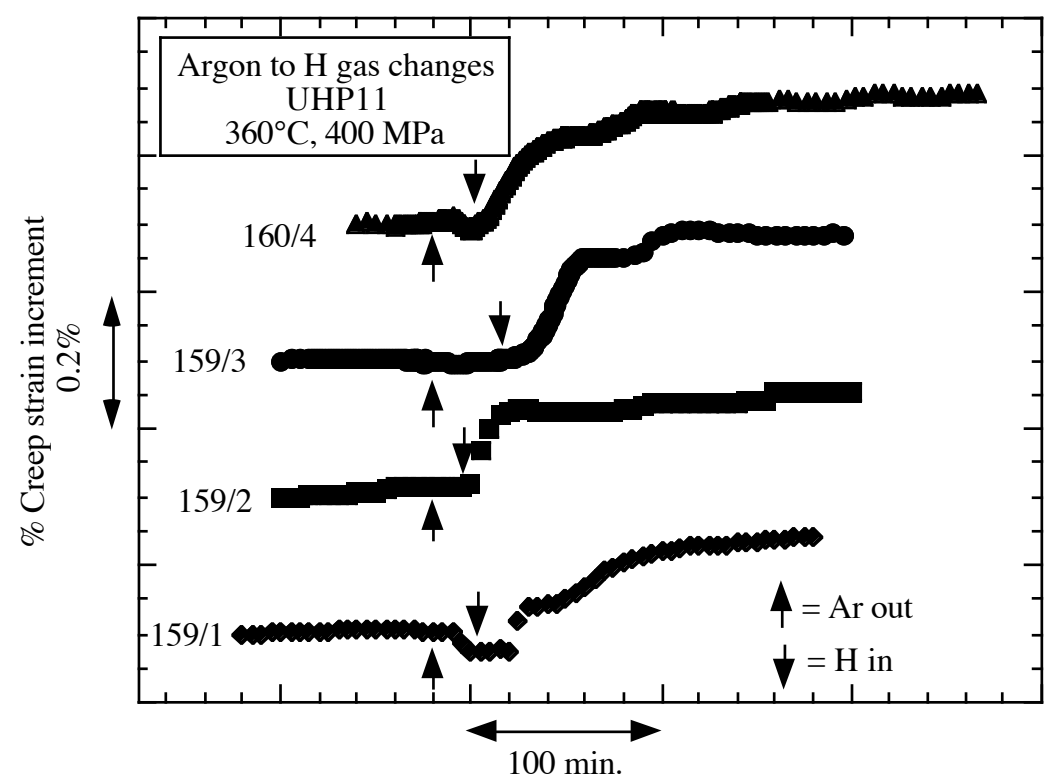

Time increment (min.)

Figure 1: Percent creep strain vs. time showing the detail of the strain transients observed when the gas in the retort is changed from argon to hydrogen. Tests 159/1 - 3 were performed on the same sample, while test $160 / 4$ was a separate sample.

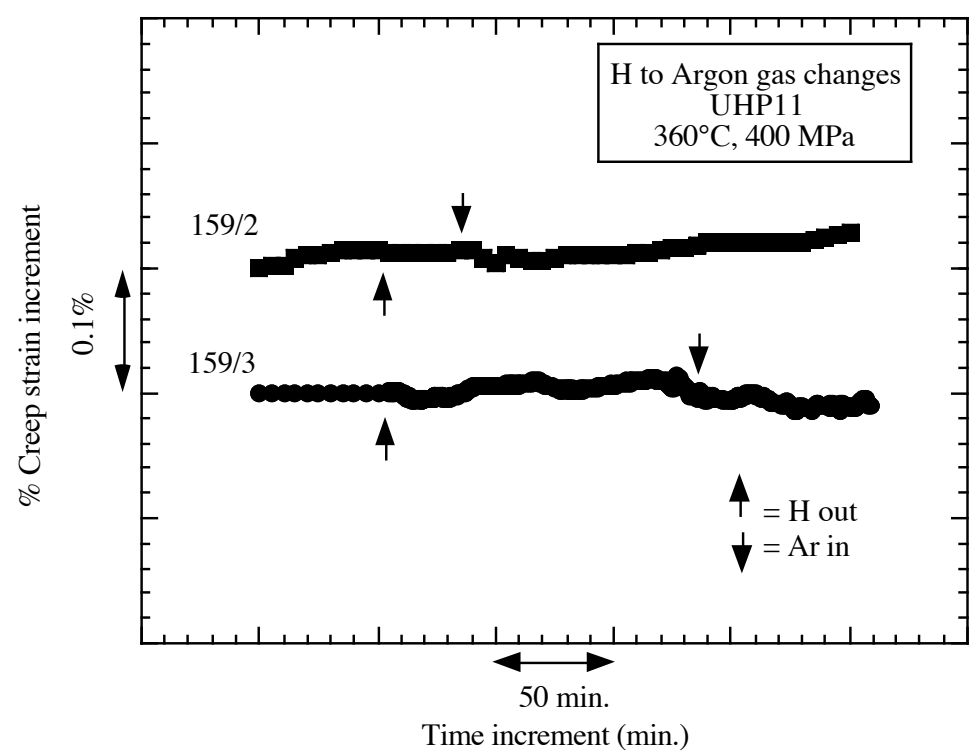

Figure 2: Percent creep strain vs. time showing the detail of the experiments in which the gas was changed from hydrogen to argon. Note that no strain transients were observed for these cases. 


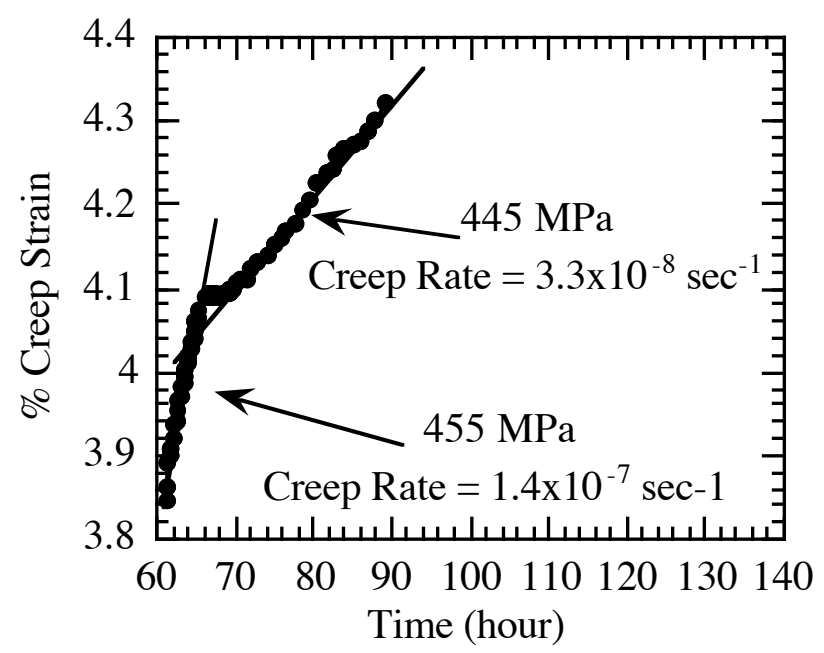

(a)

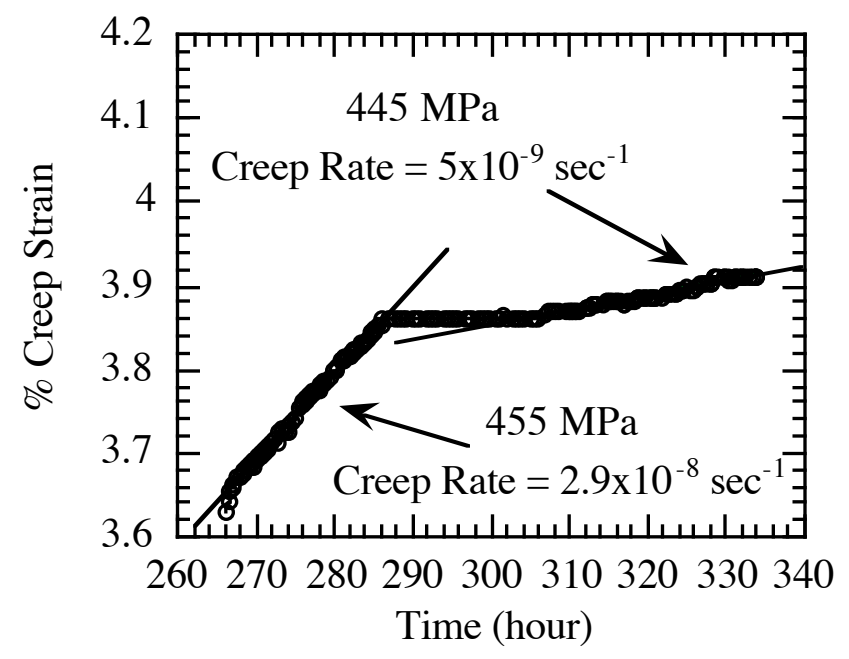

(b)

Figure 3: Examples of creep rates following $10 \mathrm{MPa}$ stress drops in a) argon (\#113) and b) primary water (\#114). 


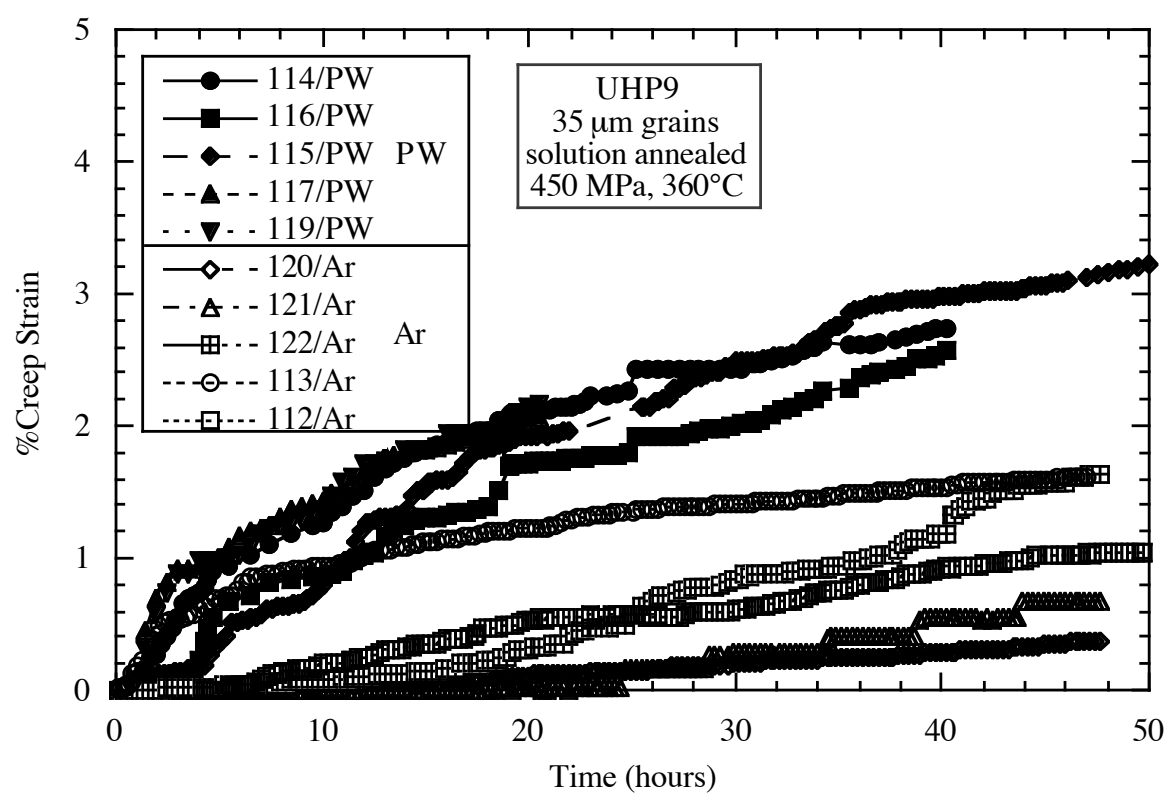

(a)

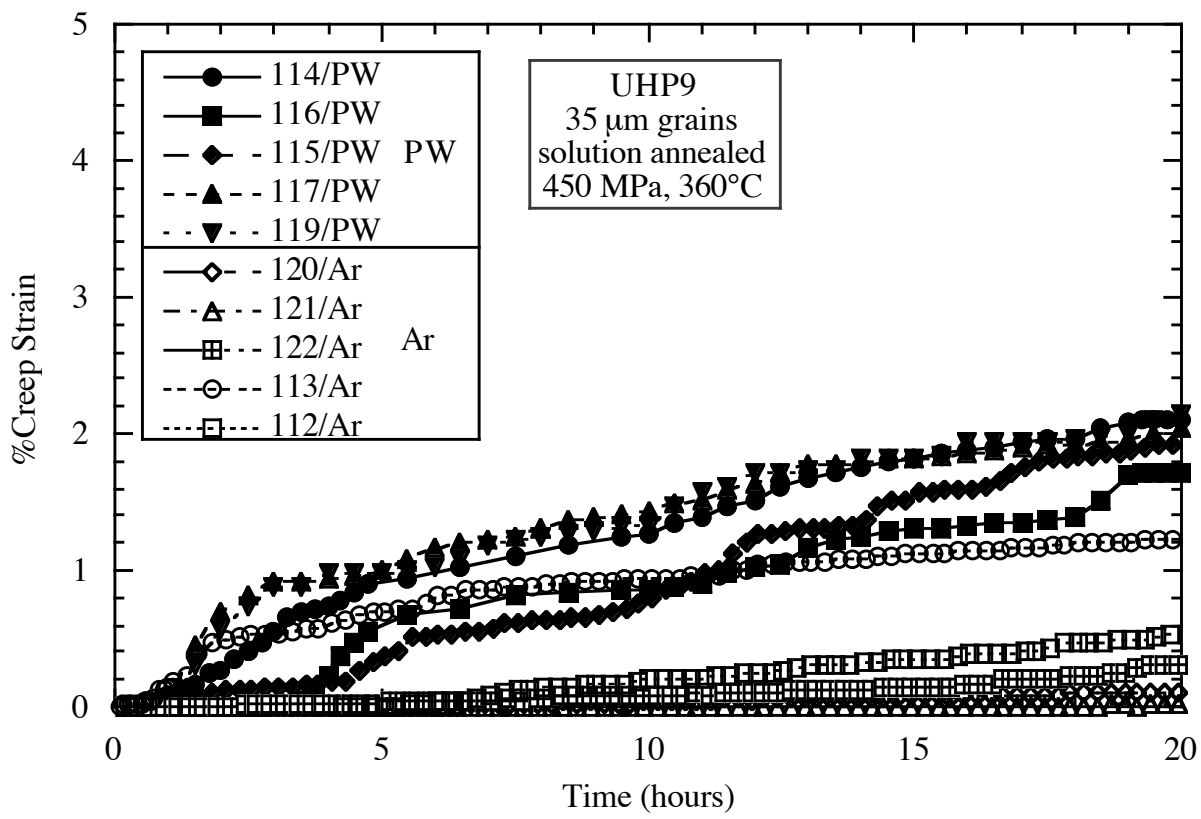

(b)

Figure 4: Percent creep strain vs. time for UHP9 showing (a) the total creep curves for load reduction tests on one sample in argon and one in primary water, and (b) the primary creep regime for several samples tested in argon and primary water at $360^{\circ} \mathrm{C}$ and an initial load of 450 $\mathrm{MPa}$. 


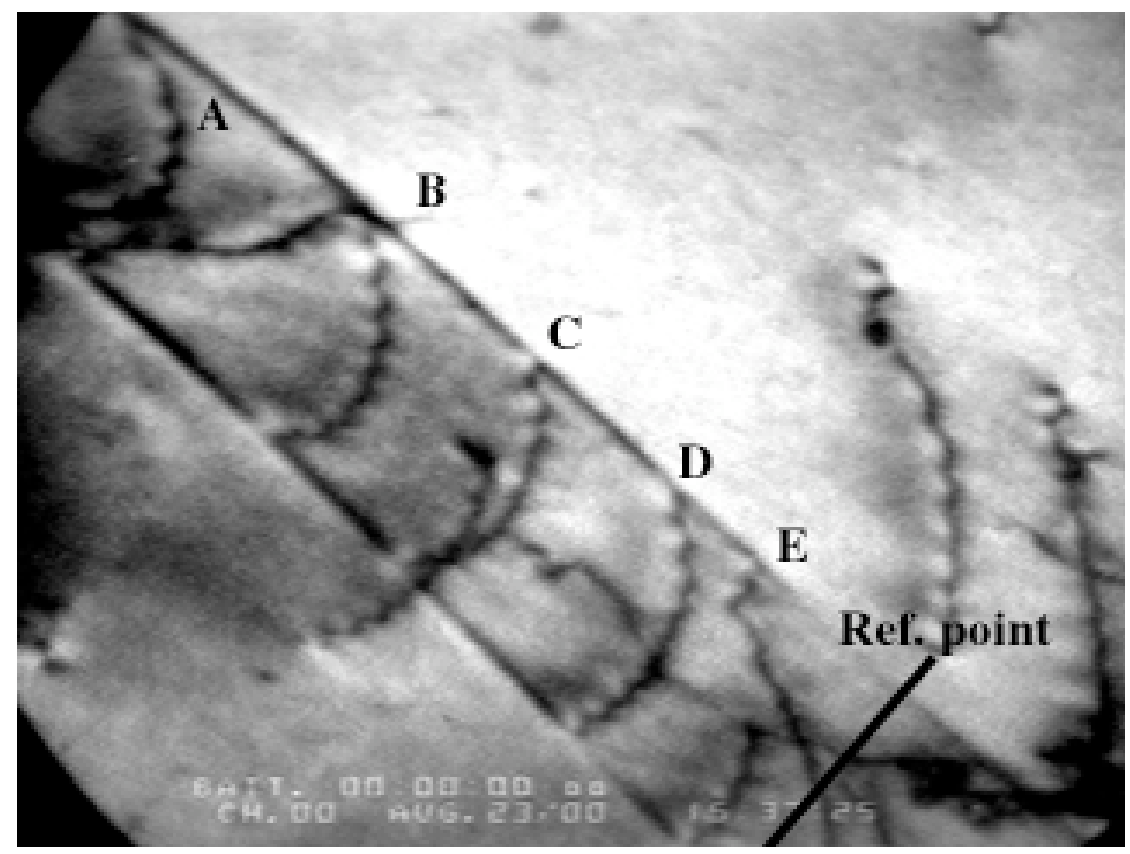

(a)

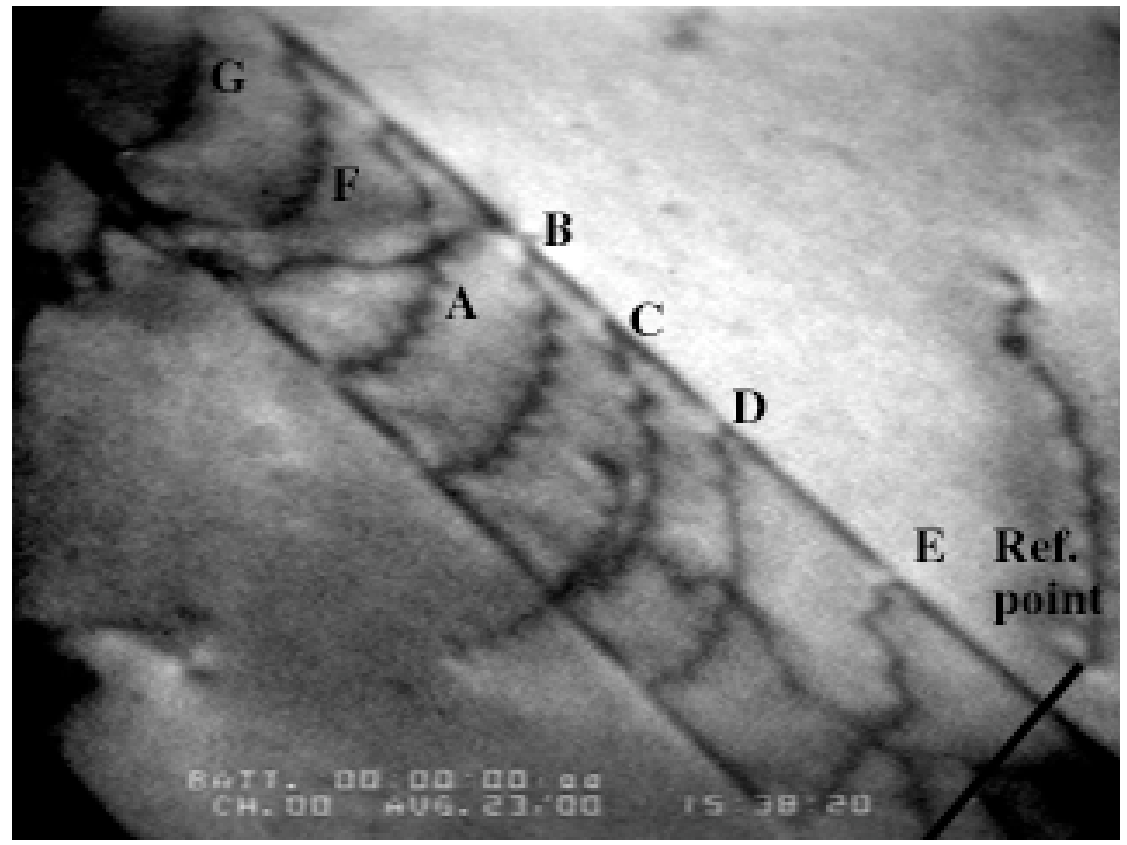

(b)

Figure 5: Dislocation pileup (a) before and (b) after the introduction of 80 torr of hydrogen introduced into the environmental cell of the HVEM. The UHP10 alloy was strained at room temperature. 


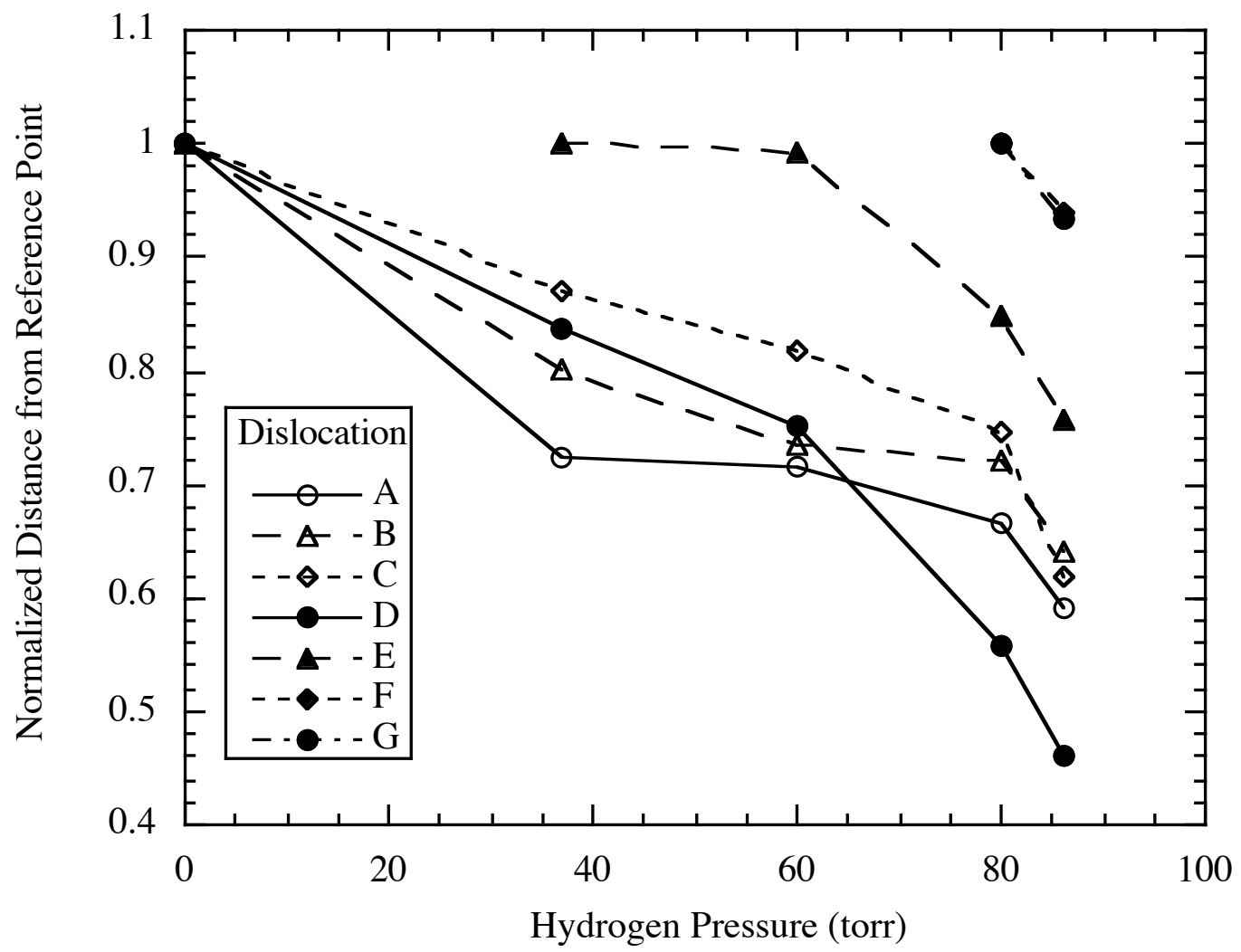

Figure 6: Relative change in spacing between dislocations as a function of the hydrogen pressure in the environmental cell in the HVEM.

\section{SELECTIVE INTERNAL OXIDATION AS A MECHANISM FOR IGSCC}

The mechanism of selective internal oxidation (SIO) to explain intergranular stress corrosion cracking (IGSCC) was presented by Peter Scott [3]. The basis of this model is that in an alloy where a minor element readily oxidizes but cannot form a protective film, it may oxidize preferentially at the grain boundary. Oxidation at the grain boundaries may lead to embrittlement and intergranular cracking. The model also relies on the inability of the major element to form it's own protective passive film. For IGSCC of nickel-base alloys, Ni is the major element and $\mathrm{Cr}$ is the minor element. Therefore, a series of experiments using high purity alloys of $\mathrm{Ni}-\mathrm{Cr}-\mathrm{Fe}$ were be conducted in a controlled environment in which either $\mathrm{Ni}$ is stable or can oxidize to form a protective film, but in which $\mathrm{Cr}$ oxidizes in all cases. By examining the 
general cracking behavior as well as the localized oxide formations, the validity of SIO can be examined.

\subsection{Controlled Environment Test System}

A controlled environment test system was constructed at the University of Michigan High Temperature Corrosion Laboratory. The unit consists of a steam supply system and a high temperature constant extension rate tensile (CERT) test frame. The steam supply system provides a mixture of low-pressure steam, hydrogen gas and argon gas. The ratios of the components determine oxidizing potential of the environment used for high temperature CERT tests. To determine the ratio of the gases, the hydrogen and argon partial pressures are determined based on the inlet flow gas composition and the water vapor partial pressure is determined by directly measuring the dew point temperature. The gas is held at a constant 5 psig pressure to ensure sealing and is not recirculated. The controlled gas mixture flows through a heated stainless steel vessel holding the tensile samples in a Cortest CERT frame. A computer acquisition system allows for monitoring of experimental parameters (temperature, load, displacement, etc.) and control of the CERT motor using a custom LabView program.

\subsection{Measurement of $\mathrm{Ni} / \mathrm{NiO}$ Transition}

The stability of $\mathrm{NiO}$ is critical to the mechanism of internal oxidation. Therefore, the test system must allow for tests in either oxidizing or non-oxidizing conditions. The partial pressure ratio is the ratio of the partial pressure of water vapor to that of hydrogen and is defined as:

$$
P P R=\frac{P_{H_{2} \mathrm{O}}}{P_{\mathrm{H}_{2}}} .
$$

The PPR is the variable that controls the oxidizing condition of the cell. High values of PPR should create non-oxidizing conditions and low values should promote oxidation.

Experiments were conducted at $400^{\circ} \mathrm{C}$ in a series of tests that cover the PPR range from 0.001 to 0.9 . O/Ni peak ratios measured by EDS are plotted in Fig. 7 and give a semiquantitative measure of the amount of oxide formed. Values above 0.1 indicate oxidation of the sample. For all alloys at low PPR values, the peak ratios clearly indicate formation of oxide, while high PPR values result in low peak ratios, indicative of the lack of a surface oxide. For alloys containing less than $16 \% \mathrm{Cr}$, a transition occurs at approximately 0.09 where the ratio 
drops, indicating no surface oxide is present. Using the standard free energy of formation for $\mathrm{NiO}$ obtained by Morton in aqueous systems, [4] the predicted transition PPR is 0.109 . Our results are in good agreement with this measured value. For alloys containing greater than $16 \%$ $\mathrm{Cr}$, the peak ratio remains high throughout the PPR range due to the dominance of $\mathrm{Cr}$ in the formation of a surface film.

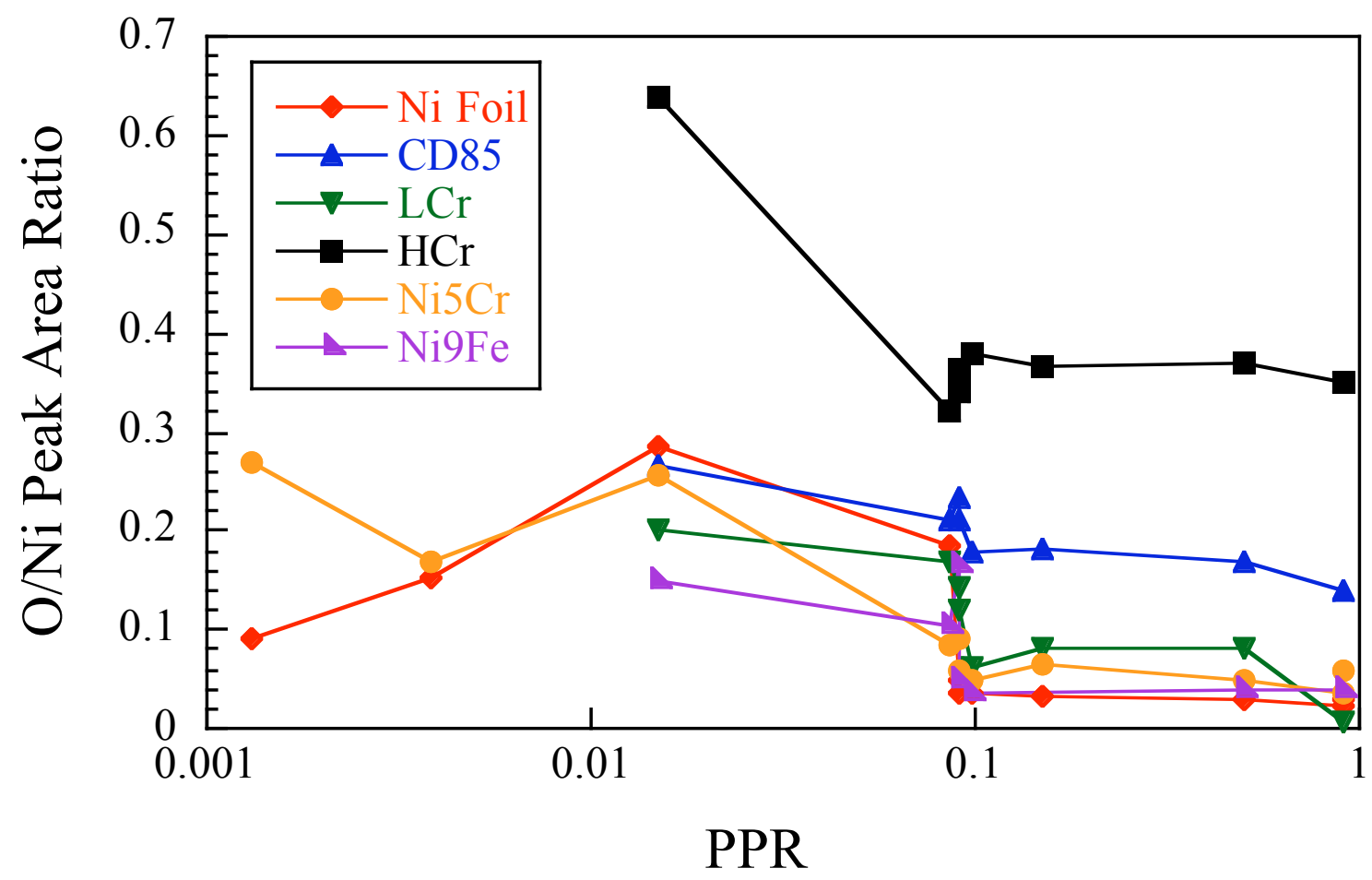

Figure 7: EDS oxide measurement for high purity Ni samples as a function of PPR at $400^{\circ} \mathrm{C}$. A transition from oxide-stable to metal-stable occurs at a PPR of approximately 0.1 .

\subsection{CERT Tests at $400^{\circ} \mathrm{C}$}

A series of CERT experiments were conducted at $400^{\circ} \mathrm{C}$. One series focused on the effect of alloy composition for both nickel oxidizing and nickel non-oxidizing conditions. Samples were strained until approximately $20 \%$ plastic deformation. After testing, samples were inspected via SEM for cracks, and the cracked boundary fraction was tabulated. These results are shown in Fig. 8. Samples tested in an oxidizing environment generally showed a higher cracked boundary fraction than those tested in a Ni-stable environment. Further, for alloys 
where many grain boundaries cracked, an oxidizing environment lead to the appearance of smooth open grain boundary facets (Fig. 9a) as opposed to the dimpled appearance from the same alloy after testing in a Ni-stable environment (Fig 9b).

A second series of experiments focused on the finer effect of testing environment using only the $\mathrm{Ni}-16 \% \mathrm{Cr}-9 \% \mathrm{Fe}$ alloy samples strained to $10 \%$ plastic deformation. Figure 10 plots the cracked boundary fraction after testing as a function of PPR. Cracked grain boundary fraction increases with decreasing PPR. However, very low PPR values were not examined since testing was concentrated on the $\mathrm{Ni} / \mathrm{NiO}$ stability transition region. It is interesting to note that an increase in cracking with surface film formation seems to oppose the SIO model of Scott. One factor not accounted for is the protective nature of the surface film. If the films formed in the $400^{\circ} \mathrm{C}$ controlled steam environments are highly porous, they may not allow for adequate passivation and oxide-grain boundary diffusion may actually lead to an increase in intergranular cracking.

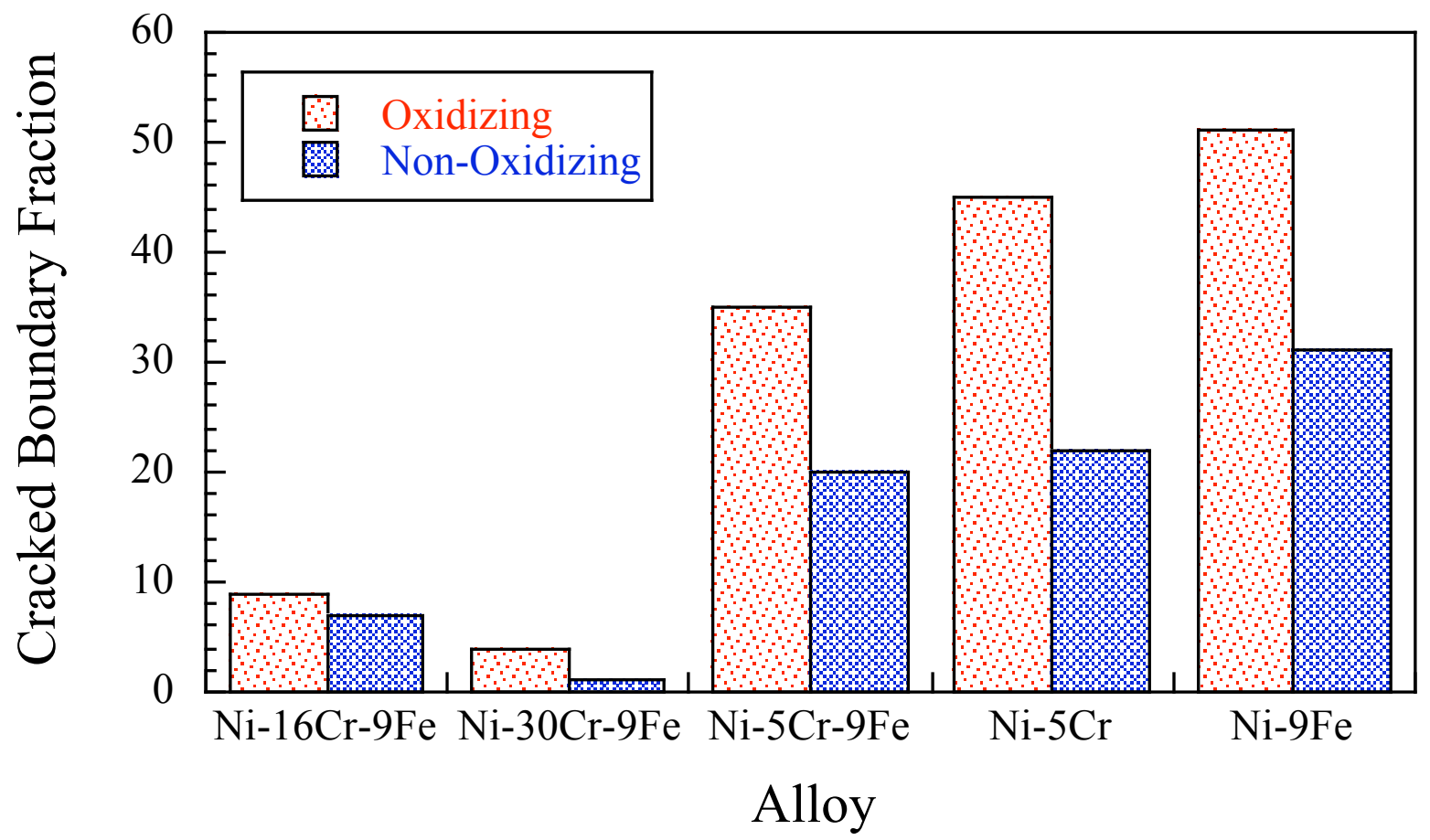

Figure 8: Cracked boundary fraction for CERT bars tested at $400^{\circ} \mathrm{C}$ for approximately $20 \%$ plastic deformation. 

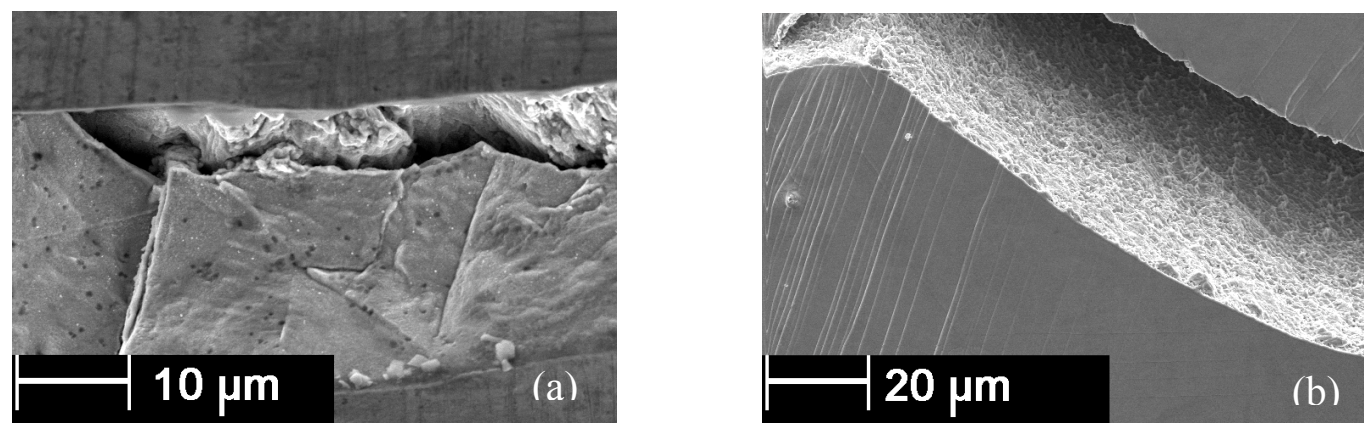

Figure 9: Intergranular cracks on $\mathrm{Ni}-5 \% \mathrm{Cr}$ samples from (a) oxidizing and (b) non-oxidizing environments.

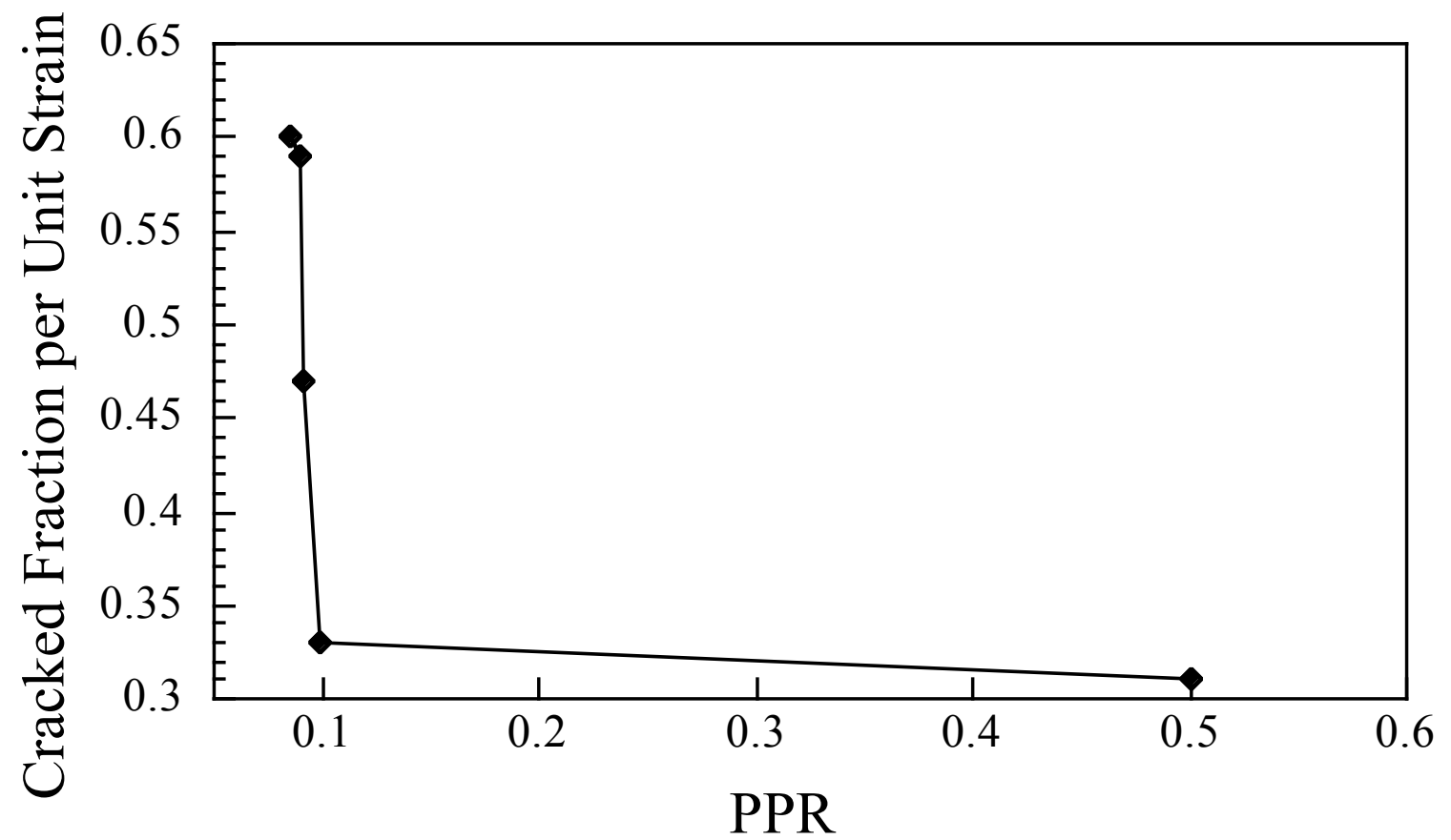

Figure 10: Cracked boundary fraction per unit strain as a function of PPR for $\mathrm{Ni}-16 \% \mathrm{Cr}-9 \% \mathrm{Fe}$ tested at $400^{\circ} \mathrm{C}$ until $10 \%$ plastic deformation.

\subsection{Localized Oxides}

Oxidation was not observed to occur uniformly on some exposure coupons tested along with CERT bars. Table 2 shows the general trends grouped by alloy type and test environment. For samples containing Fe and free of a complete oxide film, small particles $(<100 \mathrm{~nm})$ rich in Fe 
and $\mathrm{O}$ could be found decorating the grain boundaries (Fig. 11a). For samples containing $5 \% \mathrm{Cr}$, a region of increased $\mathrm{Cr}$ and $\mathrm{O}$ can be found very close to grain boundaries (Fig. 11b). These formations indicate that localized oxidation can occur at grain boundaries.

Table 2: Localized oxidation behavior for all alloys tested at $400^{\circ} \mathrm{C}$.

\begin{tabular}{|c|l|l|l|}
\hline \multirow{2}{*}{ Alloy } & NiO & $\begin{array}{l}\text { Thick } \\
\text { Surface }\end{array}$ & \\
& Stable? & Film? & GB Local Oxide Noticed \\
\hline \multirow{2}{*}{$\mathrm{Ni}$} & $\mathrm{Y}$ & $\mathrm{Y}$ & - \\
\cline { 2 - 4 } & $\mathrm{N}$ & $\mathrm{N}$ & None \\
\hline \multirow{2}{*}{ Ni-16Cr-9Fe } & $\mathrm{Y}$ & $\mathrm{Y}$ & - \\
\cline { 2 - 4 } & $\mathrm{N}$ & $\mathrm{Y}$ & - \\
\hline \multirow{2}{*}{ Ni-30Cr-9Fe } & $\mathrm{Y}$ & $\mathrm{Y}$ & - \\
\cline { 2 - 4 } & $\mathrm{N}$ & $\mathrm{Y}$ & - \\
\hline \multirow{2}{*}{$\mathrm{Ni}-5 \mathrm{Cr}-9 \mathrm{Fe}$} & $\mathrm{Y}$ & $\mathrm{Y}$ & - \\
\cline { 2 - 4 } & $\mathrm{N}$ & $\mathrm{N}$ & Particles, Cr rich region \\
\hline \multirow{2}{*}{$\mathrm{Ni}-5 \mathrm{Cr}$} & $\mathrm{Y}$ & $\mathrm{Y}$ & - \\
\cline { 2 - 4 } & $\mathrm{N}$ & $\mathrm{N}$ & Cr rich region \\
\hline \multirow{2}{*}{$\mathrm{Ni}-9 \mathrm{Fe}$} & $\mathrm{Y}$ & $\mathrm{Y}$ & - \\
\cline { 2 - 4 } & $\mathrm{N}$ & $\mathrm{N}$ & Particles \\
\hline
\end{tabular}

Thick surface film interfered with GB local Oxide Observations
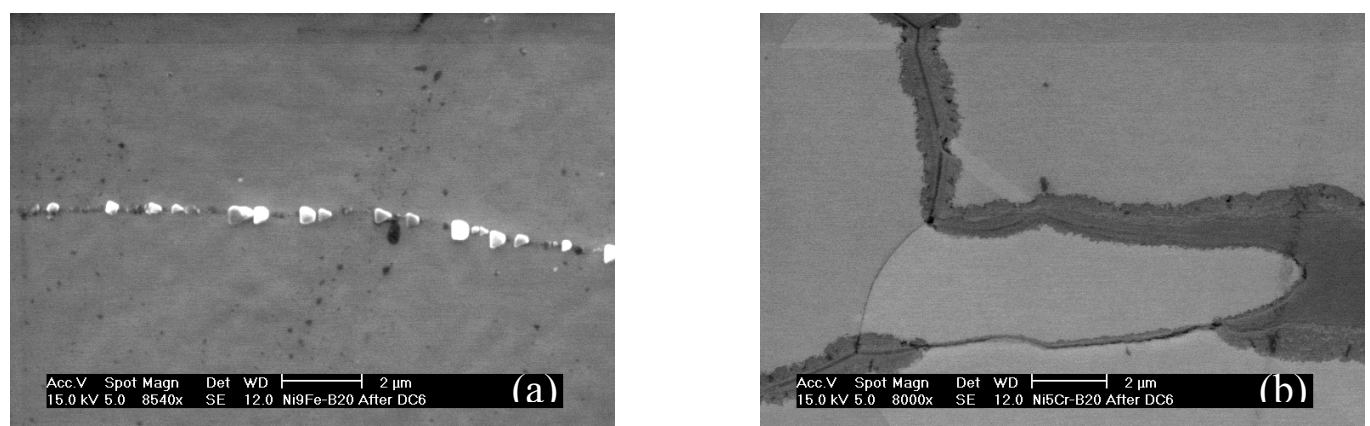

Figure 11: Localized oxide formations observed at grain boundaries after testing at $400^{\circ} \mathrm{C}$ in a non-Ni oxidizing environment. (a) Fe particles in $\mathrm{Ni}-9 \% \mathrm{Fe}$. (b) $\mathrm{Cr}$ rich region in $\mathrm{Ni}-5 \% \mathrm{Cr}$.

\subsection{Conclusions}

- The environmental control system can successfully be used to control the partial pressure ratio in controlled manor. Measurements of the $\mathrm{Ni} / \mathrm{NiO}$ transition agree well with recent data for aqueous systems. 
- For samples tested at $400^{\circ} \mathrm{C}$, environment has an effect on the amount and appearance of intergranular cracking. Oxidizing environments tend to result in the largest susceptibility to cracking. It is suggested that oxide film protectiveness may play a large role in the observed cracking behavior.

- Localized oxides can be found on the surface of unstressed corrosion specifically at the grain boundaries. For Fe containing alloys, the oxides appear as small $(<100 \mathrm{~nm})$ particles. For $\mathrm{Cr}$ containing alloys, a localized region enhanced in $\mathrm{Cr}$ could be found near grain boundaries. The appearance of these features indicates that localized oxidation does occur at grain boundaries.

\section{ROLE OF GRAIN BOUNDARIES IN DEFORMATION OF Ni- $16 \mathrm{Cr}-9 \mathrm{Fe}-\mathrm{xC}$ at $360^{\circ} \mathrm{C}$}

The objective of this study was to determine whether grain boundary deformation plays a direct role in intergranular stress corrosion cracking of Ni-16Cr-9Fe in high temperature water. The difference in deformation and cracking behavior between special grain boundaries, or coincident site lattice boundaries (CLSB), and high angle boundaries (HAB) was exploited to determine if a cause-and-effect exists between grain boundary deformation and IGSCC. It was hypothesized that coincident site lattice boundaries (CSLBs) are less susceptible to deformation than general (random) high angle boundaries (HABs), and are, therefore, less susceptible to cracking. The hypothesis was substantiated by showing that 1) the dislocation absorption kinetics differ substantially between CSLBs and HABs, resulting in different susceptibilities to deformation, and 2) grain boundary deformation is a precursor to intergranular stress corrosion cracking.

\subsection{Dislocation Annihilation Kinetics and Effect on Local Hardness}

The difference in dislocation annihilation kinetics at CSLBs and HABs was determined by TEM on samples annealed at $360^{\circ} \mathrm{C}$ [5]. Results showed that extrinsic grain boundary dislocations (EGBDs) are annihilated at HABs at a rate that is, on average, 3 times that at CLSBs, Fig. 12. The activation energies for grain boundary diffusion were estimated to be $Q_{\text {HАB }}$ $=231 \mathrm{~kJ} / \mathrm{mole}$ and $Q_{\mathrm{CSLB}}=244 \mathrm{~kJ} / \mathrm{mole}$, implying a grain boundary diffusion coefficient in CSLBs is 12 times lower than that in HABs. The latter observation further implies that under 
similar stress conditions the amount of sliding experienced by a HAB should be on the average 12 times greater than that of a CSLB. The expectation that a reduced EGBD absorption at CSLBs would lead to greater matrix hardening was investigated using nanohardness measurements. Results showed that the hardness in the vicinity of CSLBs is greater than that near HABs, Fig. 13, and the grain-averaged hardness increases with the fraction of contiguous CSLBs. Moreover, strain-hardening was found to be greater in samples having increased proportions of CSL boundaries or CSL-enhanced (CSLE) than in reference, solution annealed (SA) samples, Fig. 14.

\subsection{Effect of CSLs on Grain Boundary Deformation and Cracking}

The difference in deformation behavior was investigated by SEM examination of samples strained at $360^{\circ} \mathrm{C}$ in an inert environment [6]. Following $10 \%$ plastic straining in $360^{\circ} \mathrm{C} \mathrm{Ar}$, $52 \%$ of the HABs and $15 \%$ of the CSLBs were found to display deformation. The possible linkage between deformation and cracking was probed by comparing the deformation data with cracking data for the same alloy resulting from 10\% strain in primary water. Figure 15 shows the fractions of deformed (a) and cracked (b) HAB boundaries as functions of the angle $\square$ with respect to the tensile direction. The solid lines represent the averaged grain boundary shear stress. Although the averaged resolved shear stress appears to only roughly approximate the angular distributions of deformed and cracked fractions, the similarity of Figs. 15a and 15b suggests that the driving force behind grain boundary deformation - the resolved shear stress - is also implicated in the cracking process. The direct relationship between grain boundary deformation and IGSCC was demonstrated by further exposing the samples on which the deformation study was conducted to an additional $5 \%$ strain in $360^{\circ} \mathrm{C}$ primary water. Resulting analysis showed that $61 \%$ of the boundaries that deformed in argon also cracked in water while only $17 \%$ of cracked boundaries showed no prior deformation in argon, Fig. 16. These results show that there is a cause-and-effect relationship between grain boundary deformation and IGSCC. As well, the activation energy for grain boundary diffusion driving grain boundary deformation, $Q_{\mathrm{HAB}}=231 \mathrm{~kJ} / \mathrm{mole}$, is comparable to that for IGSCC initiation (212-241 kJ/mole), suggesting that grain boundary deformation is also the rate limiting factor for crack initiation. 


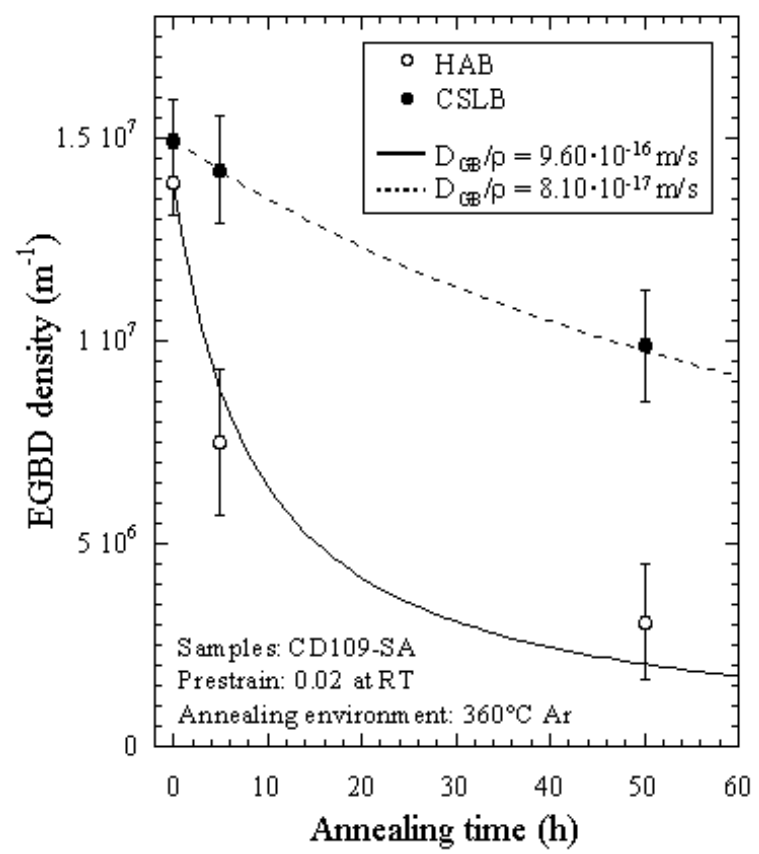

Figure 12. Extrinsic grain boundary dislocation density vs. annealing time at $360^{\circ} \mathrm{C}$ in $\mathrm{CD} 109$ SA Ni-16Cr-9Fe alloy.

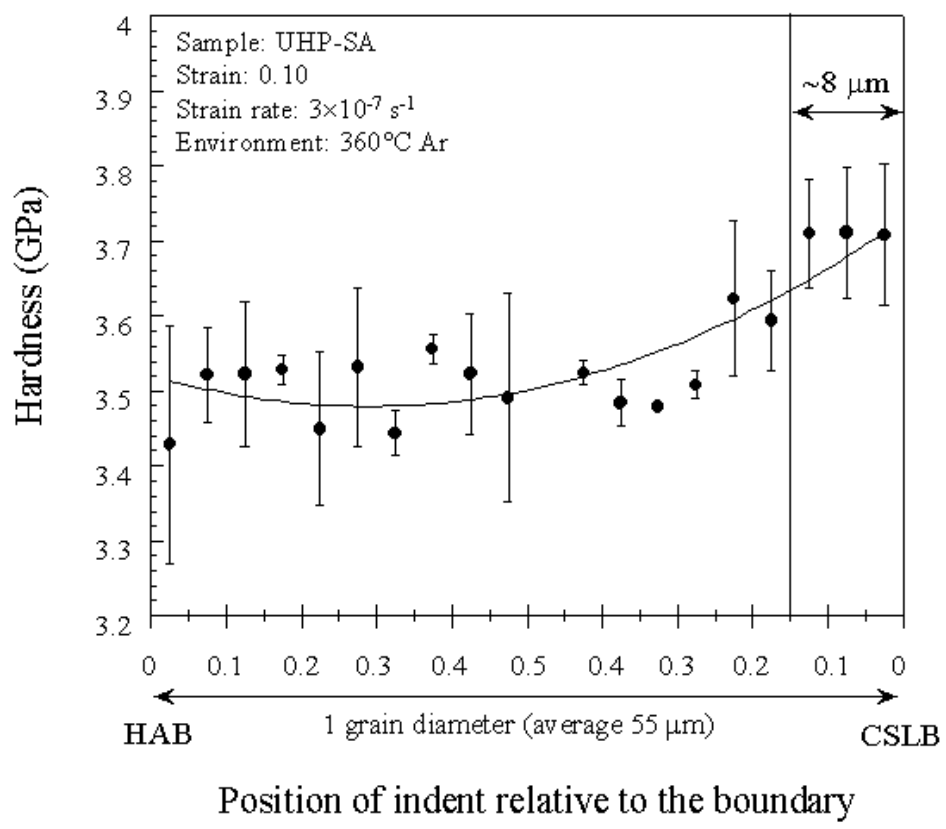

Figure 13. Hardness as a function of the normalized position of indents relative to the nearest boundary in $55 \square \mathrm{m}$ average diameter grains in UHP-SA alloy deformed to $10 \%$ strain in $360^{\circ} \mathrm{C}$ Ar. 


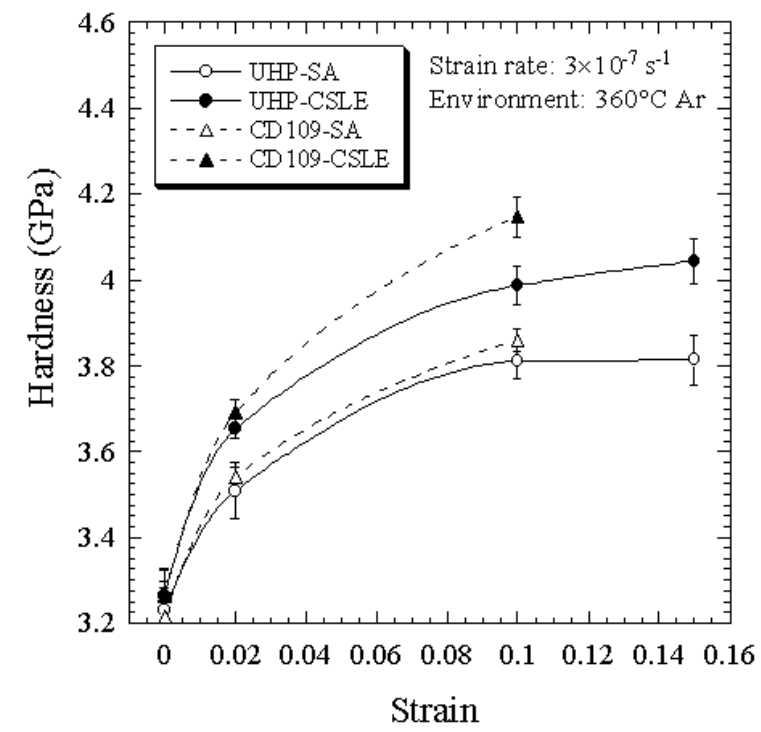

Figure 14. Hardness as a function of strain for reference SA and CSL-enhanced samples made of UHP and CD109 alloys, deformed in $360^{\circ} \mathrm{C}$ Ar.

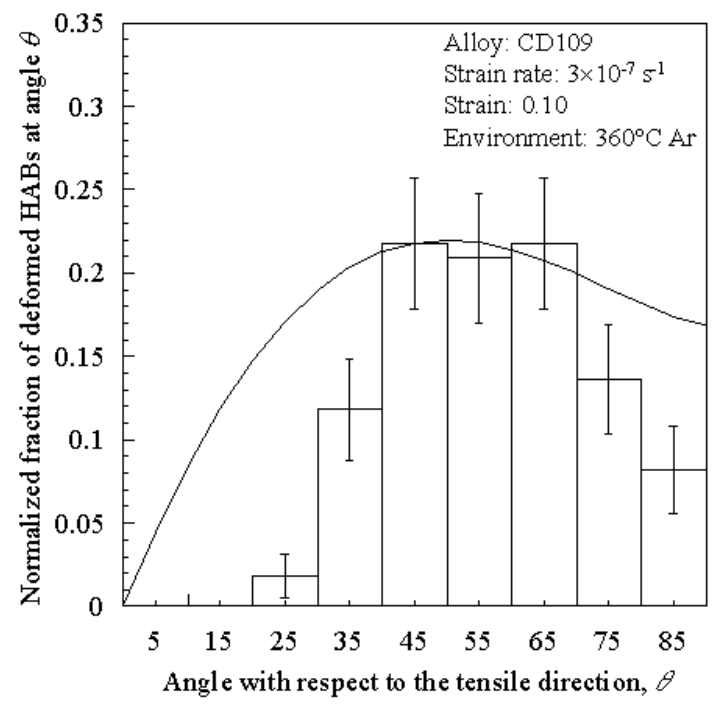

a

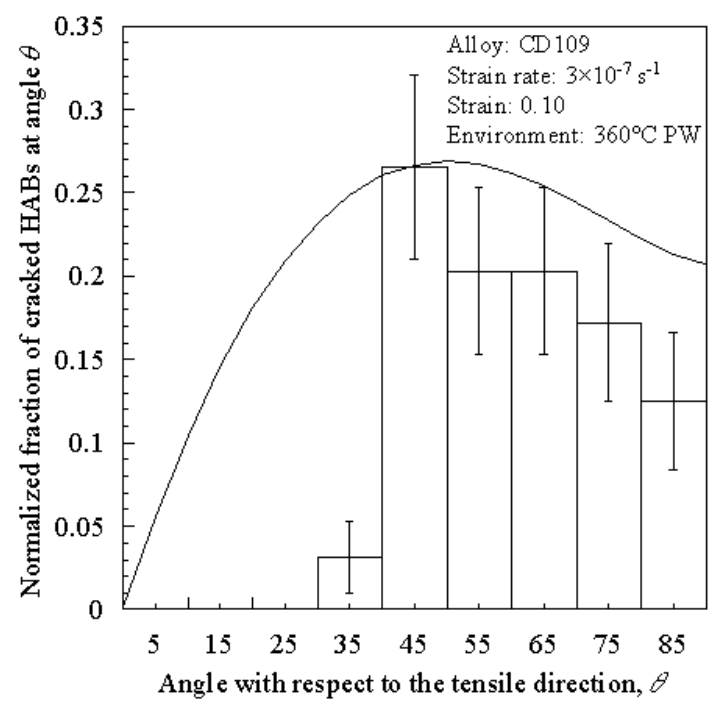

$\mathrm{b}$

Figure 15. The normalized fractions of deformed HAB boundaries (a) and cracked HAB boundaries (b) as a function of angle with respect to the tensile direction. All samples were strained to 0.10 in $360^{\circ} \mathrm{C} \mathrm{Ar}$ (a) and $360^{\circ} \mathrm{C}$ primary water (b) at a strain rate $3 \square 10^{-7} \mathrm{~s}^{-1}$. The solid curves represent the average normalized shear stress resolved on the grain boundary plane 


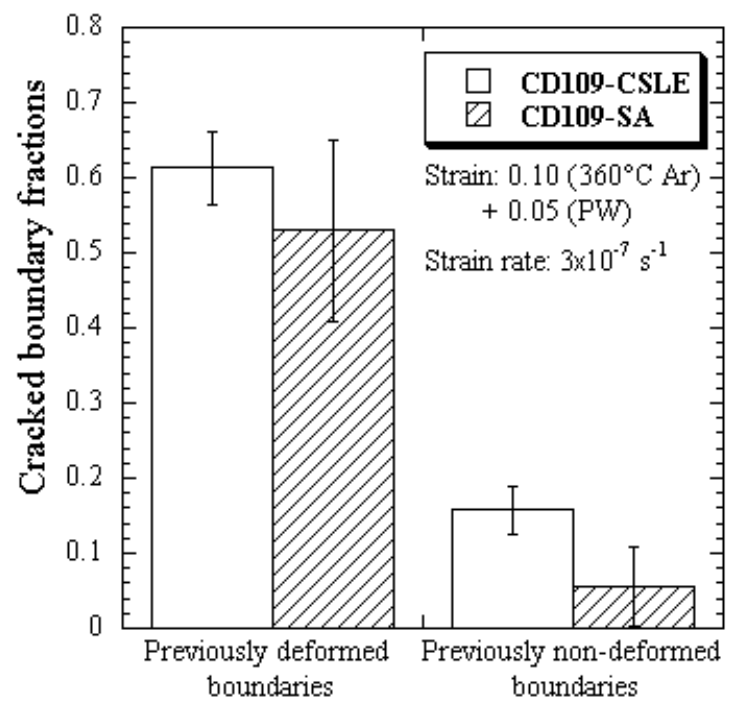

Figure 16. Susceptibility to cracking of previously deformed and previously non-deformed boundaries irrespective of the grain boundary type.

\section{MAXIMIZING IGSCC RESISTANCE THROUGH CONTROL OF CSLBs AND GBCs}

The combined effect of coincident site lattice enhancement (CSLE) and grain boundary carbide (GBC) decoration has been investigated for the purpose of maximizing resistance to IGSCC through microstructure control. A matrix of eight samples was tested to verify the effect of CSLE, GBC and the combination of both features on IGSCC in a primary water environment. The samples and preparations used are presented in Table 3 and allow for nearly direct cross comparison among alloys, CSLB levels, and GBC conditions.

\subsection{Grain Boundary Characterization}

Prior to testing, the grain boundary character distributions of all samples were measured using a TexSEM $\square$ OIM system attached to a Philips XL-30 FEG SEM. OIM scans were performed on an area $400 \square \mathrm{m} \times 700 \square \mathrm{m}$ with a step size of $6 \square \mathrm{m}$. Each scan area was sufficient to yield approximately 160 grain boundaries. At least 4 separate areas were used on each sample. The grain boundary character distribution is plotted in Fig. 17. The effect of the CSLE process is to increase the fraction of coincident site lattice boundaries (CSLBs) by about $10 \%$ for a given alloy from around $20 \%$ to in excess of $30 \%$. Also note that the character distribution varies 
between the samples with some non-CSLE samples having nearly the same CSLB fraction as some CSLE samples.

The effect of grain boundary carbides was evaluated using the alloy containing 109 wppm carbon. Using the DEPLETE code, [7] a heat treatment was planned to precipitate carbon as GBC until 65 wppm carbon was left in solution. This treatment allows for isolation of the effect of GBC apart from the carbon remaining in solution by comparing results to samples with 65 wppm carbon all in solid solution. Samples were etched to reveal carbides and carbide levels were also recorded.

\subsection{Constant Extension Rate Experiments in Primary Water}

Testing was performed at the University of Michigan in the High Temperature Corrosion Laboratory in a 1.71 autoclave mounted on a constant extension rate (CERT) system.

Experiments were conducted at an initial strain rate of $3 \times 10^{-7} \mathrm{~s}^{-1}$ at a temperature of $360^{\circ} \mathrm{C}$ with a pressure of 2800 psi. The simulated primary water (PW) environment consisted of flowing, deaerated $\left(<5 \mathrm{ppb} \mathrm{O}_{2}\right)$, high purity $(>18 \mathrm{M} \square-\mathrm{cm})$ water with the addition of $0.001 \mathrm{M} \mathrm{LiOH}+$ $0.01 \mathrm{M} \mathrm{H}_{3} \mathrm{BO}_{3}$ and a hydrogen overpressure of $0.10 \mathrm{MPa}$.

Straining was interrupted at $10 \%, 15 \%, 20 \%$ and $25 \%$ strain to assess grain boundary cracking propensity. All samples were strained until 25\% strain was reached except for sample UHP-CSLE which was damaged during reinsertion after 15\% strain, and the CD65SA+GBC sample which reached only $20 \%$ strain. At each interruption, samples were removed from the autoclave and examined in a Philips XL30 FEG SEM. The same areas previously scanned with the OIM were relocated and photographed. Cracked boundaries were identified and logged by inspection of the micrographs.

Total cracking fractions for all alloy conditions are plotted as Fig. 18. The trend clearly shows a monotonically increasing fraction of cracked boundaries with strain. To examine the role of CSLBs in cracking, the ratio between the CSLB cracked fraction and the HAB cracked fraction was plotted as a function of strain. Figure 19 shows that all data lie well below a cracked fraction ratio of 1.0, meaning that irrespective of alloy, processing conditions or strain, CSLBs are less susceptible to cracking than HABs.

The presence of grain boundary carbides augments the improvement of IGSCC resistance afforded by CSLBs. Figure 20 shows the total cracked boundary fraction as a function of CSLB 
content for the four alloy conditions over the strain range $15 \%$ to $20 \%$. This figure shows the effect of all three microstructure features on IGSCC; CSLB fraction, carbon content and grain boundary carbides. Note that irrespective of strain level and alloy, higher CSLB contents result in lower cracked grain boundary fractions. In particular, the high CSLB fraction of the CD65+GBC condition resulted in very low cracked fractions compared to that in the low CSLB fraction UHP alloy. Second, the role of carbon in solution is also evident in showing that the IGSCC resistance increases with solution carbon content. Finally, grain boundary carbides provide an additional measure of resistance to IGSCC above that from the CSLB fraction or higher $\mathrm{C}$ level alone or in combination with each other. Note that compared with the CD65CSLE sample, the CD65-CLSE+GBC condition shows lower grain boundary cracking.

The decrease in IG cracking with grain boundary carbides is modest and less than observed by Hertzberg and Was [8] and Was and Lian [9]. The difference may be due in part to the measurement of different quantities. Hertzberg and Was measured crack depth distributions which include both the initial stage of crack formation and some degree of propagation. Results presented here focused only on crack initiation as determined from examination of the sample surface. The implication is that carbides may be effective not only in inhibiting crack initiation, but also in impeding propagation as suggested.

Table 3: Summary of thermal-mechanical treatments used in this study.

\begin{tabular}{|c|c|}
\hline Sample Designation & Thermal-mechanical Treatment \\
\hline UHP-SA & SA $20 \min .1025^{\circ} \mathrm{C}+45 \%$ compression $+70 \min .800^{\circ} \mathrm{C}$ \\
\hline UHP-CSLE & $\begin{array}{l}\text { SA } 20 \min .1025^{\circ} \mathrm{C}+40 \% \text { compression }+70 \min .800^{\circ} \mathrm{C} \\
\text { Followed by: } 3 \text { cycles: } 3 \% \text { strain }+7.5 \min .925^{\circ} \mathrm{C}\end{array}$ \\
\hline CD109-SA & $\mathrm{SA} 20 \min .1025^{\circ} \mathrm{C}+40 \%$ compression $+10 \min .850^{\circ} \mathrm{C}$ \\
\hline CD109-CSLE & $\begin{array}{l}\mathrm{SA} 20 \min .1025^{\circ} \mathrm{C}+40 \% \text { compression }+10 \min .850^{\circ} \mathrm{C} \\
\text { Followed by: } 3 \text { cycles: } 3 \% \text { strain }+7.5 \min .925^{\circ} \mathrm{C}\end{array}$ \\
\hline CD65-SA & $\mathrm{SA} 20 \min .1100^{\circ} \mathrm{C}+45 \%$ compression $+10 \min .850^{\circ} \mathrm{C}$ \\
\hline CD65-CSLE & $\begin{array}{l}\text { SA } 20 \min .1025^{\circ} \mathrm{C}+45 \% \text { compression }+10 \min .800^{\circ} \mathrm{C} \\
\text { Followed by: } 3 \text { cycles: } 3 \% \text { strain }+7.5 \min .925^{\circ} \mathrm{C}\end{array}$ \\
\hline CD65/GBC-SA & $\begin{array}{l}\text { SA } 20 \min .1100^{\circ} \mathrm{C}+45 \% \text { compression }+10 \min .850^{\circ} \mathrm{C} \\
\text { Followed by: } 60 \mathrm{~min} .700^{\circ} \mathrm{C}\end{array}$ \\
\hline CD65/GBC-CSLE & $\begin{array}{l}\text { SA } 20 \min .1100^{\circ} \mathrm{C}+35 \% \text { compression }+10 \min .850^{\circ} \mathrm{C} \\
\text { Followed by: } 3 \text { cycles: } 3 \% \text { strain }+7.5 \min .925^{\circ} \mathrm{C} \text { and } 60 \mathrm{~min} .700^{\circ} \mathrm{C}\end{array}$ \\
\hline
\end{tabular}




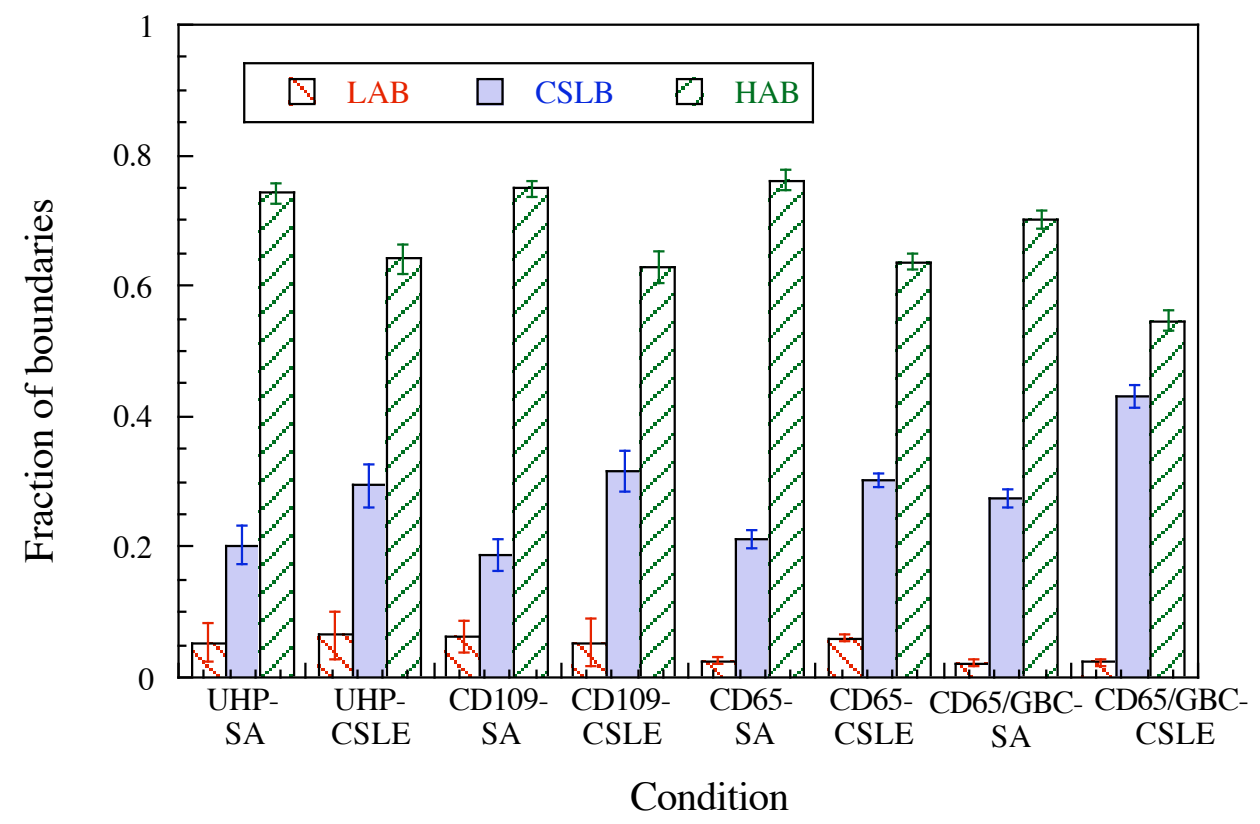

Fig. 17: Grain boundary character distribution for the eight alloy conditions used in this study. Fractions are determined from the number of each boundary type after exclusion of coherent $\square 3$ (twin) boundaries.

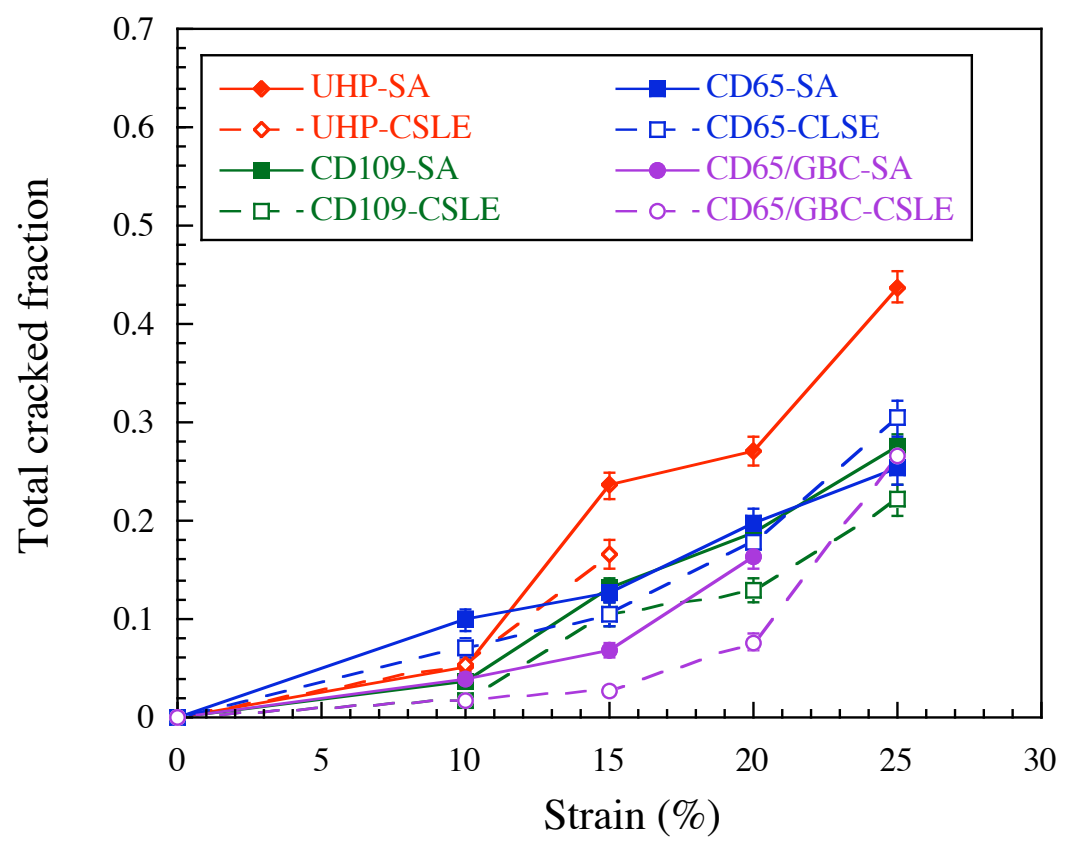

Fig. 18: Total grain boundary cracked fraction vs. strain as a function of alloy condition for samples tested in $360^{\circ} \mathrm{C}$ primary water at a strain rate of $3 \times 10^{-7} \mathrm{~s}^{-1}$. 


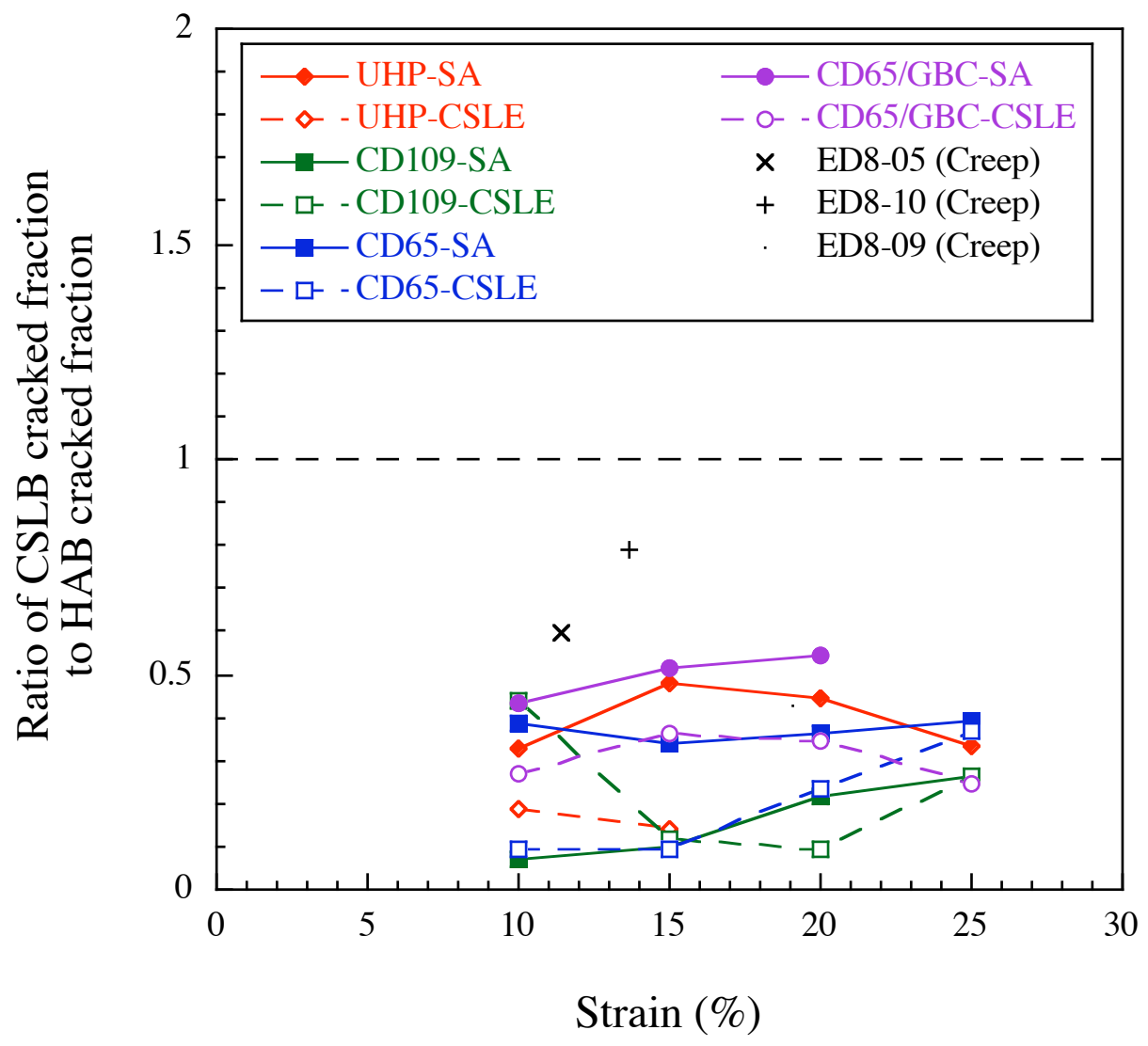

Fig. 19: Ratio of the fraction of cracked HABs to cracked CSLBs as a function of strain for the same conditions as for Fig. 2. The three additional data points are from commercial mill annealed alloy 600 in constant load creep tests in a similar environment. 


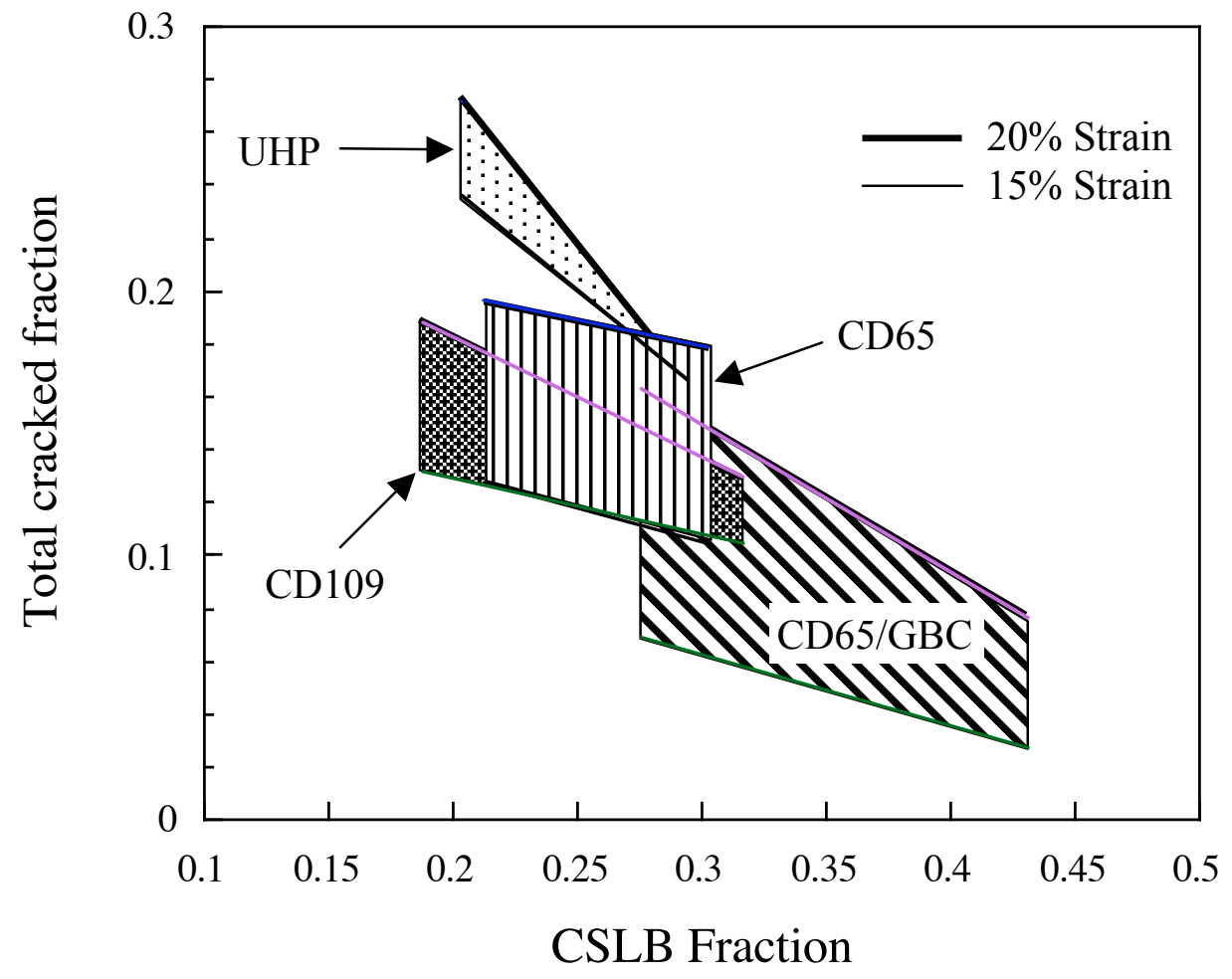

Fig. 20: Dependence of total cracked fraction on CSLB fraction for varying levels of carbon in solution and for the case of grain boundary carbides for strains of $15 \%$ and $20 \%$ after testing in $360^{\circ} \mathrm{C}$ primary water at a strain rate of $3 \times 10^{-7} \mathrm{~s}^{-1}$. 


\section{REFERENCES}

1. D. Paraventi and G. S. Was, "Environmentally-Enhanced Deformation of Ultra High Purity Ni-16Cr-9Fe Alloys", Metall. Trans. A, 31A (2000) 2383-2388.

2. C. R. Barrett and W. D. Nix, "A Model for Steady State Creep Based on the Motion of Jogged Screw Dislocations," Acta Metall. 13 (1965) 1247-1258.

3. P. M. Scott, and M. Le Calvar,"Some Possible Mechanisms of Intergranular Stress Corrosion Cracking of Alloy 600 in PWR Primary Water" 6th International Conference on Environmental Degradation of Materials in Nuclear Power Systems - Water Reactors, The Metallurgical Society of AIME, Warrendale, PA (1993), pp. 657-667.

4. D. S. Morton, S. Attanasio, and G. A. Young, "Primary Water SCC Understanding and Characterization Through the Fundamental Testing in the Vicinity of the Nickel/Nickel Oxide Phase Transition," 10th International Conference on Environmental Degradation of Materials in Nuclear Power Systems - Water Reactors, National Association of Corrosion Engineers, Houston, TX, 2001.

5. B. Alexandreanu, B.H. Sencer, V. Thaveeprunsriporn and G.S. Was, "The effect of grain boundary character distribution on the high temperature deformation behavior of $\mathrm{Ni}-16 \mathrm{Cr}$ 9Fe alloys," Acta Materialia 51 (2003) 3831-3848.

6. B. Alexandreanu and G.S. Was, "Grain boundary deformation-induced intergranular stress corrosion cracking of Ni-16Cr-9Fe in $360^{\circ} \mathrm{C}$ water," Corrosion 59(8) (2003) 705-720.

7. G.S. Was and R. Kruger, "A Thermodynamic and Kinetic Basis for Understanding Chromium Depletion in Ni-Cr-Fe Alloys," Acta Metallurgica, 33 (1985) 841-854.

8. J. Hertzberg and G. S. Was, "Role of Carbon in the Deformation and Fracture of Ni-16Cr9Fe alloys in $360^{\circ} \mathrm{C}$ Water," Metall. Trans. A. 29A (1998) 1035-1046.

9. G. S. Was and K. Lian, "Intergranular Stress Corrosion Cracking in Commercial Alloy 600 and Controlled-Purity Ni-16Cr-9Fe Alloys in Primary Water at $360^{\circ} \mathrm{C}$," Corrosion, 54, No. 9 (1998) 675-688. 


\section{STUDENTS}

Denise Paraventi received her Ph.D. degree for her thesis entitled, "Effect of Hydrogen on Creep in Ni-16Cr-9F3 in High Temperature Water," in June, 2000. Denise is now a staff scientist at Bettis Laboratory.

Bogdan Alexandreanu received his Ph.D. degree for his thesis entitled, "Mechanism by which Special Grain Boundaries Improve Creep and IGSCC in Ni-base Alloys in High Temperature Water," in April, 2002. Bogdan is now employed in the Materials Division at Argonne National Laboratory.

Brent Capell is completing the requirements for his Ph.D. degree on the topic, "Assessment of the role of Selective Internal Oxidation in the IGSCC of Ni-base alloys in High Temperature Water and Steam," and is expected to receive his degree in the summer of 2004. 


\title{
7. PUBLICATIONS
}

\author{
$\underline{\text { Journal Articles }}$
}

B. Alexandreanu and G. S. Was, "Grain Boundary Deformation - Induced Intergranular Stress Corrosion Cracking of Ni-16Cr-9Fe in $360^{\circ} \mathrm{C}$ Water," Corrosion, 59, No. 8 (2003) 705-720.

B. Alexandreanu, B. H. Sencer, V. Thaveeprungsriporn and G. S. Was, "The Effect of Grain Boundary Character Distribution on the High Temperature Deformation Behavior of Ni-16Cr9Fe alloys, Phil. Mag., 51, No. 13 (2003) 3831-3848.

D. Paraventi, T. Angeliu and G. S. Was, "Effect of Hydrogen on Creep of High Purity Ni-16Cr9Fe at $360^{\circ} \mathrm{C}, "$ Corrosion 58 (8) (2002) 687-697.

B. Alexandreanu, B. Capell and G. S. Was, "Combined Effect of Special Grain Boundaries and Grain Boundary Carbides on IGSCC of Ni-16Cr-9Fe-xC Alloys," Mater. Sci. Engin. A, 300 Nos. 1-2 (2001) 94-104.

B. Alexandreanu and G. S. Was, "A Priori Determination of the Sampling Size for Grain Boundary Character Distribution and Grain Boundary Degradation Analysis," Phil. Mag. A., 81, No. 8 (2001) 1951-1965.

D. Paraventi and G. S. Was, "Environmentally-Enhanced Deformation of Ultra High Purity Ni16Cr-9Fe Alloys", Metall. Trans. A, 31A (2000) 2383-2388

\section{Conference Articles}

G. S. Was, B. Alexandreanu and J. Busby, "Localized Deformation-Induced IGSCC and IASCC of Austenitic Alloys in High Temperature Water," Proc. 2nd International Conference on Physics and Chemistry of Fracture and Failure Prevention (PCFFP) and the 5th International Conference on Fracture and Strength of Solids organized by Far East and Oceanic Fracture Society(FEOFS), in press.

L. Fournier, B. Capell, T. Magnin and G.S. Was, "Oxidation Induced Intergranular Cracking in Nickel Base Alloys in the Temperature Range $400^{\circ} \mathrm{C}$ to $650^{\circ} \mathrm{C}$," Proc. Hydrogen Effects/Corrosion Deformation Interactions, 2003, The Minerials, Metals and Materials Society, Warrendale, PA, pp. 837-848

D. J. Paraventi, T. M. Angeliu and G. S. Was, "The Effect of Hydrogen on Creep in High Purity $\mathrm{Ni}-16 \mathrm{Cr}-9 \mathrm{Fe}$ Alloys at $360^{\circ} \mathrm{C}$," Proc. Hydrogen Effects/Corrosion Deformation Interactions, 2003, The Minerials, Metals and Materials Society, Warrendale, PA, pp. 799-810.

B. Alexandrenau, H. Sencer and G. S. Was, "Deformation and IGSCC Behavior of CSL and High Angle Boundaries in Ni-Cr-Fe-C Alloys," Proc. Hydrogen Effects/Corrosion Deformation Interactions, 2003, The Minerials, Metals and Materials Society, Warrendale, PA, pp 771-790.

B. Capell, L. Fournier and G. S. Was, "Intergranular Cracking Behavior of Ni-xCr-9Fe-C Alloys in Hydrogenated Steam," $10^{\text {th }}$ Int'l Conf. Environmental Degradation of Materials in Nuclear Power Systems - Water Reactors, NACE International, Houston, TX, 2002. 
G. S. Was, B. Alexendreanu, B. Capell, V. Thaveeprungsriporn, T. M. Angeliu, J. L. Hertzberg, D. Crawford, D. Paraventi, F. Vaillant, "The Role of Grain Boundary Deformation in IGSCC of Austenitic Alloys in High Temperature Water," Proc. Chemistry and Electrochemistry of Stress Corrosion Cracking: A Symposium Honoring the Contributions of R. W. Staehle, R. H. Jones, ed., The Minerals, Metals and Materials Society, 2001, pp. 145-165.

B. Capell, L. Fournier and G. S. Was, "Intergranular Cracking Behavior of Ni-xCr-9Fe-C Alloys in Hydrogenated Steam," $10^{\text {th }}$ Int'l Conf. Environmental Degradation of Materials in Nuclear Power Systems - Water Reactors, 2002, NACE International, Houston, TX, submitted.

B. Alexandrenau, B. M. Capell and G. S. Was, "The Effect of Special Grain Boundaries on IGSCC of Ni-16Cr-9Fe-xC," Proc. $9^{\text {th }}$ International Conference on Environmental Degradation of Materials in Nuclear Power Systems - Water Reactors, Minerals, Metals and Materials Society, Warrendale, PA, 2000, pp. 157-165. 